Review Article

\title{
On the Recent Trends in Expansive Soil Stabilization Using Calcium-Based Stabilizer Materials (CSMs): A Comprehensive Review
}

\author{
Fazal E. Jalal $\mathbb{D},{ }^{1,2}$ Yongfu Xu $\mathbb{D},{ }^{1,2,3}$ Babak Jamhiri $\mathbb{D}^{1},{ }^{1}$ and Shazim Ali Memon $\mathbb{D}^{4}$ \\ ${ }^{1}$ State Key Laboratory of Ocean Engineering, Shanghai Jiao Tong University, Shanghai 200240, China \\ ${ }^{2}$ Department of Civil Engineering, Shanghai Jiao Tong University, Shanghai 200240, China \\ ${ }^{3}$ Wentian College of Hohai University, Ma'anshan 243000, China \\ ${ }^{4}$ Department of Civil and Environmental Engineering, Nazarbayev University, Nur-Sultan 010000, Kazakhstan
}

Correspondence should be addressed to Yongfu Xu; yongfuxu@sjtu.edu.cn and Shazim Ali Memon; shazim.memon@nu.edu.kz

Received 15 October 2019; Revised 12 December 2019; Accepted 27 January 2020; Published 10 March 2020

Guest Editor: Andrea Graziani

Copyright (c) 2020 Fazal E. Jalal et al. This is an open access article distributed under the Creative Commons Attribution License, which permits unrestricted use, distribution, and reproduction in any medium, provided the original work is properly cited.

Calcium-based stabilizer materials (CSMs) exhibit pozzolanic properties which improve the properties of clayey soils by hydration, cation exchange, flocculation, pozzolanic reaction, and carbonation. In this comprehensive review, comprising over past three decades from 1990 to 2019, a mechanistic literature of expansive soil stabilization by incorporating CSMs is presented by reviewing 183 published research articles. The advantages and disadvantages of CSMs as the ground stabilizing agent are succinctly presented, and the major outcomes of physicochemical effects on soil properties are discussed in detail. After blending with CSM, the main and interaction effects on soil properties with focus on chemical processes such as X-ray fluorescence, X-ray diffraction analyses, and microstructure interaction by using scanning electron microscopy and thermogravimetric analysis have been reviewed in light of findings of past researchers. This work will help geotechnical engineers to opt for suitable CSM in the field of geoenvironmental engineering in committing to sustainable construction of civil engineering structures over expansive soils.

\section{Introduction}

The behavior of fine-grained soils is largely governed by moisture content variations. Upon interaction with water, the clay particles in such soils are primarily responsible for the expansive nature and hence called "expansive" or "swelling" soils [1]. Among others, the main clay minerals in expansive soils include illite, kaolinite, and montmorillonite (further on referred to as Mt). Owing to the hydrophilic nature and high dispersivity of the clay minerals, they cause high risk to the civil engineering foundations, to landslides triggering [2], and to the road subgrades [3] especially before bituminous coating as soil improvement additives or cold mixtures [4-7]. For practical implications in engineering, the treatment of expansive soils is imperative. The mechanical and chemical soil stabilization improves the engineering characteristics of the problematic soils [8].
Stabilization of soil may be expensive, but it decreases the overall construction cost of buildings and road subgrades [9]. In order to improve the behavior of expansive soils, geotechnical engineers seek help from soil science and geology. The first modern use of soil stabilization was introduced in 1904 in the USA [10]. Brashad [10] explained the phenomenon of clay expansion due to water considering the various interlayer cations in 1950. Petry and Little [10] investigated the stabilization of expansive soils by evaluating the effectiveness of traditional calciumbased stabilizer materials (CSMs) in their state-of-thepractice stabilization during 1940 and 2001. Simons [11] discussed the microstructural processes, chemical interactions, and the waste reuse and sustainability in an attempt to modify expansive soil properties. In yet another study, Behnood [12] reviewed the comparison of calcium (Ca) based and non-Ca-based stabilizers with detailed 
discussions on techniques and challenges in soil modification. According to Godenzoni [13], the cementing materials (CMs) are produced by the most conventional stabilizing materials, that is, lime, cement, and their mixes along with other pozzolanic materials. Today, a detailed literature is available, and a worldwide research on expansive soil stabilization using a wide array of classical and emergent materials is still in progress [14-22]. Although well-documented studies on the use of numerous stabilizers are available, to these authors', knowledge, no study made between 1990 and 2019 that explains the main and interaction effects of CSMs on the expansive soils, has been found. Also, the standardization for various additives is unavailable in the field of geotechnical engineering which leads to geoenvironmental issues and affects the environment. This comprehensive review serves three main objectives on the following subjects: (1) gain insights about the history, mechanism, damages associated, and prevalence of expansive soils over last 30 years, (2) review the practice of efficacious stabilization using Ca-based stabilizer materials for civil engineering structures and road pavements, and (3) serve a guideline for researchers and practitioners to select materials under the domain of this study.

\section{Fundamental Knowledge about Stabilization of Expansive Soils}

2.1. Mechanism. Improvement in properties of an expansive or problematic soil means increase in the compressive strength and permeability, reduction in plasticity and compressibility, and improvement in durability of these soils. More concisely, "soil stabilization" is mainly the addition of chemical admixtures to soil which results in chemical improvement [23]. Swelling in expansive soils deals mainly with prevalence of type and amount of pore spaces and their interaction with water. The phenomenon of swelling may comprise over a relatively long time ranging between 5 to 8 years during early service life of foundations and pavements [24]. Figure 1 illustrates the pore spaces between the unit layers of clays, also known as interlayer space, which represent the "microporosity," whereas pore spaces between adjacent particles or aggregates, called the interparticle pores or interaggregate pore spaces, respectively, represent the "macroporosity" in the compacted smectite particles. The water present in both these regions differ in terms of their physical states. Swelling takes place when the water enters into the interlayers. Petry and Little [10] outlined the empirical methods to determine the volume change resulted from swelling in expansive soils.

Figure 2 depicts the process of water entry inside clay plates at extended microlevel. The "clay particle" represents an interconnected stack of clay layers with a maximum four layers of crystalline water. The "clay aggregates" are the assembly of "clay particles" forming unit of a compacted clay double structure. The portion of the clay particle surface parallel to that of "clay layers" is called the "particle face." However, the part of the clay particle surface normal to the particle face is known as "particle edge." Diffuse double layers are produced around particle faces with the attached water called "double-layer water." The water other than the diffuse double layers is shown by the "equilibrium solution."

The role of diffused double layer theory comes into play while evaluating the expansivity of clay minerals. Accordingly, the repulsive and attractive forces generated by physicochemical effects are quantified on the particle scale level [26]. This theory is applicable to smectite particles present in monovalent electrolytes with lesser concentration. The thickness of the double layer is shown in the following "Poisson-Boltzmann equation":

$$
\frac{1}{K}=\sqrt{\frac{D k T}{8 \pi \eta_{0} \varepsilon^{2} V^{2}}},
$$

where $1 / K=D_{L}$, i.e., thickness of double layer $(\mathrm{cm})$, $D=$ dielectric constant, $k=$ Boltzmann constant $=1.38 *$ $10^{-23} \mathrm{~J} / \mathrm{K}, \eta_{0}=$ bulk solution of the electrolyte concentration (ions $/ \mathrm{cm}^{3}$ ), $\varepsilon=$ unit electronic charge (esu), $T=$ absolute temperature $(\mathrm{K})$, and $v=$ cation valence. Note that $D_{L}$ is directly proportional to the cation exchange capacity (CEC) and specific surface area (SSA) of clay minerals and has pronounced effect on these entities [27-29].

The clay minerals belong to "phyllosilicates" family and carry a net residual negative charge. The mechanism of clay modification by calcium-rich stabilizers involves dissociation of higher calcium content into calcium ions that react with both silica and alumina leading to the ion exchange, flocculation, and pozzolanic reactions. This process is expressed in equations (2)-(5). Also, the California bearing ratio (CBR) is increased, and the formation of two main components takes place, calcium silicate hydrates $(\mathrm{C}-\mathrm{S}-\mathrm{H})$ gel, represented by chemical formula [5 $\mathrm{Ca}_{2} \mathrm{SiO}_{4}: 6 \mathrm{H}_{2} \mathrm{O}$ ], and calcium aluminate hydrate (C-A$\mathrm{H})$ gel, with chemical formula $\left[\mathrm{Ca}_{5} \mathrm{Si}_{5} \mathrm{Al}(\mathrm{OH}) \mathrm{O}_{17} \cdot 5 \mathrm{H}_{2} \mathrm{O}\right]$. As shown in equations (4) and (5), it is due to this pozzolanic reaction that soil durability is largely improved [30]. It is also notable that, in some cases, calcium aluminate silicate hydrate (C-A-S-H) may form which also adds to the soil strength. The pozzolanic reactions occur in a highly alkaline environment gradually dissolving the aluminosilicates which also contributes to the long-term strength gain [31]. The presence of clay mineral type and calcium $\left(\mathrm{Ca}^{2+}\right)$ ions governs the effectiveness of these reactions. The volumetric stability of the soil matrix is enhanced as $\mathrm{Ca}^{2+}$ tends to replace monovalent $\mathrm{Na}^{+}$or $\mathrm{H}^{+}$ ions. Production of C-S-H and C-A-H gels in this way is called "polymerization process" $[32,33]$ :

$$
\begin{aligned}
\mathrm{CaO}+\mathrm{H}_{2} \mathrm{O} \stackrel{280 \mathrm{cal} / \mathrm{g} \longrightarrow \mathrm{CaO}}{\longrightarrow} \mathrm{Ca}(\mathrm{OH})_{2} \\
\mathrm{Ca}(\mathrm{OH})_{2} \longrightarrow \mathrm{Ca}^{2+}+2(\mathrm{OH})^{-} \\
\mathrm{Ca}^{2+}+2(\mathrm{OH})^{-}+\mathrm{SiO}_{2} \longrightarrow \mathrm{C}-\mathrm{S}-\mathrm{H} \\
\mathrm{Ca}^{2+}+2(\mathrm{OH})^{-}+\mathrm{Al}_{2} \mathrm{O}_{3} \longrightarrow \mathrm{C}-\mathrm{A}-\mathrm{H}
\end{aligned}
$$




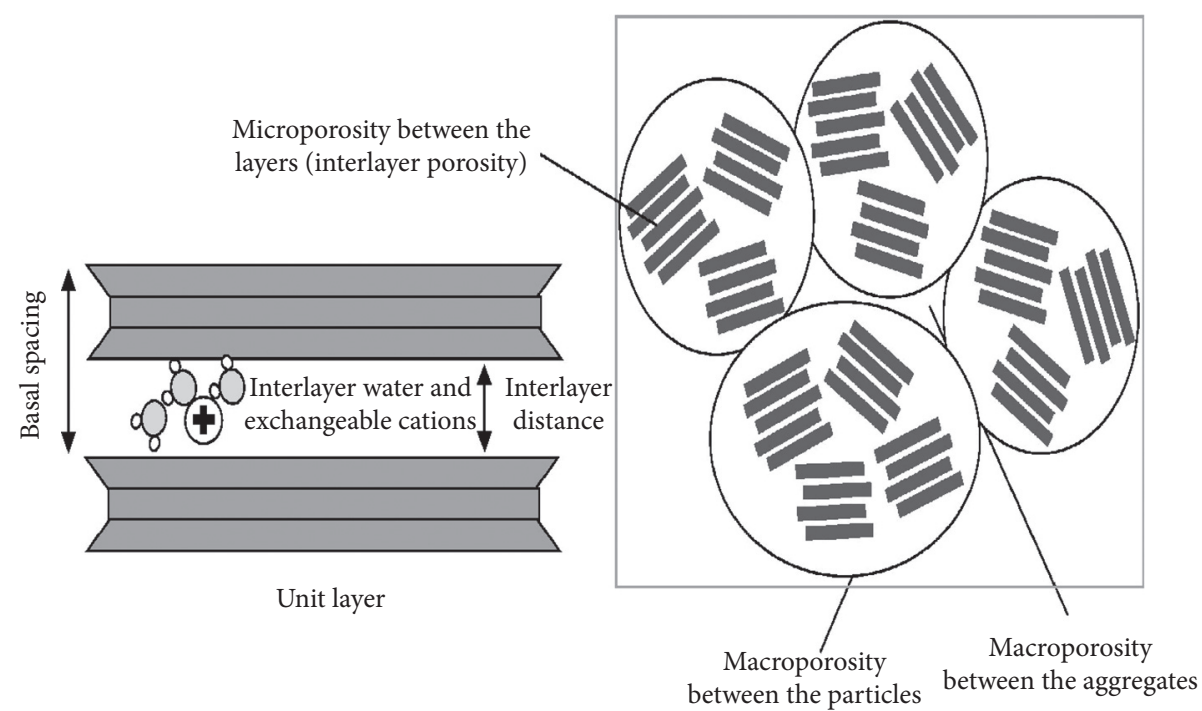

Figure 1: Effect of water entry on micro- and macroplates of compacted smectite with classification of "microporosity" and "macroporosity," reproduced with permission from [12].

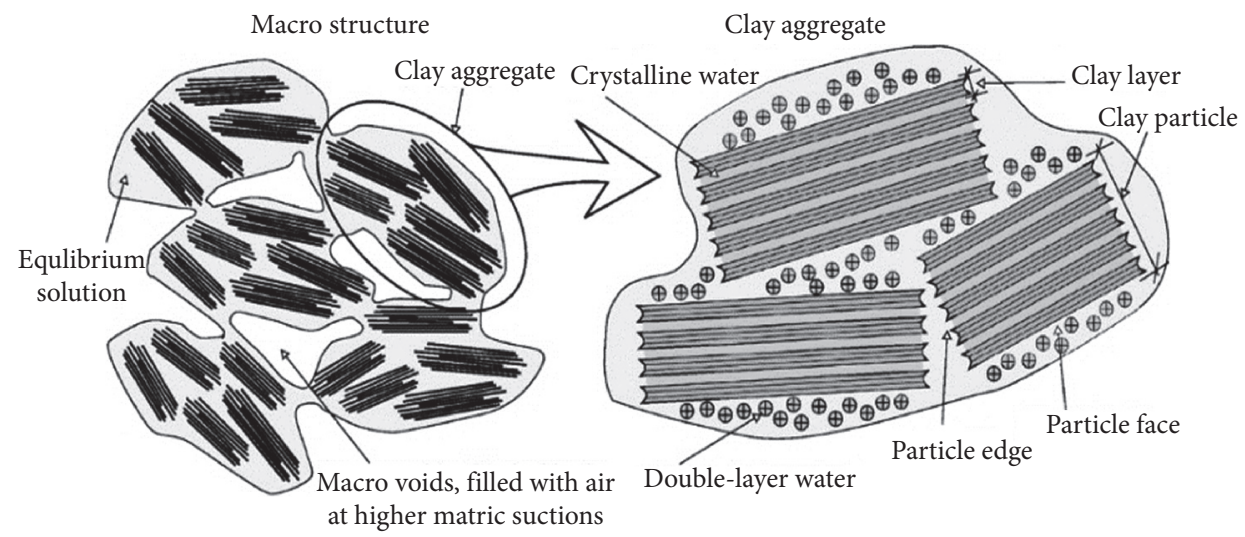

FIGURE 2: Compacted clay structure depicting the process of water entry inside clay plates at the extended microlevel, adapted from [25].

2.2. Identification and Characterization. It is essential to quantify the amount of swell pressure $\left(P_{\mathrm{s}}\right)$ exerted by expansive soil upon water uptake. Expansive soils below the ground surface level extending to a depth of approximately 1.5 meters are more susceptible to swelling pressure in the particular zone called "active zone depth." However, the region beyond the active zone depth is termed as "zone of constant volume" experiencing lesser volume change with moisture entry [28]. The susceptibility of such soils to volumetric swelling makes them highly unsuitable for use in supporting foundations. Shi et al. [29] presented the common methods to evaluate the swell intensity, i.e., free swell (FS) [34] and $P_{s}$, which were determined using simple tests such as Atterberg limits (liquid limit (LL), plastic limit (PL), and shrinkage limit (SL)), contents of colloids, and activity (A) value of clay. The LL, PL, and SL are index properties used for classification of fine-grained soils and determine the mechanical behavior, i.e., shear strength, compressibility, and swell potential [27]. According to the experimental study by Cantillo et al. [35], the Atterberg limits contribute very least statistical significance to estimation of $P_{\mathrm{s}}$ as evidenced by conducting tests on 38 samples obtained from database of material parameters. "Free Swell Index" (FSI), a measure of FS, is the increase in soil volume without any external constraints when submerged in water. " $P_{s}$ " is defined as the pressure exerted by clay when it absorbs water in a confined space. "Activity" (A), the ratio of plasticity index (PI) to the percent of clay fraction, represents the water holding capacity of clay soil and is function of type and amount of clay mineral. Activity of $\mathrm{Mt}$ (commonly greater than 4 ) is highest than for kaolinite and illite. The FS and $P_{\mathrm{s}}[28,36]$ are calculated using oedometer in accordance with ASTM standards [37]. Moreover, to determine the $P_{s}$, the zero swell test and oedometer test methods are preferable because of their ease and simple procedure $[38,39]$. For a variety of expansive soils in Egypt, it was revealed by Mehmood et al. [40] that, for highly plastic clays with activity between 0.8 and 1.5 , the swell potential parameters were calculated using the following equations: 


$$
\begin{aligned}
P_{\mathrm{s}} & =0.1266(3.6 \times \text { activity })^{3.47}, \\
\text { activity } & =0.2783(\mathrm{FS})^{0.288} .
\end{aligned}
$$

The identification and characterization of expansive soils are presented in numerous studies during the annals of history. In Table 1, the expansive soils have been classified based on swell tests, Atterberg limits, free swell ratio, dominant clay type, suction, and absorption capability. Unlike the studies in the 70's and 80's, the classifications suggested in 2000 and onwards witnessed a marked difference. For instance, according to the China Ministry of Construction (CMC 2004) classification, the expansive soils having a PI less than $15 \%$ are low expansive, whereas those exceeding $40 \%$ are high expansive soils. The latest classification methods take into account the important soil suction parameter, dominance of clay mineral, and absorption ability of the clay-rich soils in order to improve categorizing the expansive soils to a higher degree of accuracy $[45,46]$. According to latest classification based on index properties, it is alluded that clay soils with LL greater than $40 \%$, lying above the A-line on Casagrande's plasticity chart and containing more than 5\% Mt content, are known as swelling soils $[38,44,47]$.

2.3. Basic Clay Minerals. The swelling of expansive soils is mainly attributed with the presence of clay minerals such as illite, kaolinite, and $\mathrm{Mt}[48,49]$ whose mineralogical properties are listed in Table 2. The order of their expansivity is $\mathrm{Mt}>$ kaolinite $>$ illite. Mt is combination of silica tetrahedrons and alumina octahedral linked via weak Van der Waal's forces. It has high liquid limit (up to 900\%) and SSA $\left(850 \mathrm{~g} / \mathrm{cm}^{2}\right)$ values [15]. The Mt carries (1) permanent negative charge over the surface, which is function of isomorphous substitution of magnesium and iron ions [50], and (2) positive charge distributed on the edges, which is function of $\mathrm{pH}$ of the soil [36]. Kaolinite is the least expansive among the three clay minerals due to presence of fixed $\mathrm{K}^{+}$ions. Illite has an expansion index ranging between Mt and kaolinite, while its structure resembles with that of Mt. Illite has also fixed potassium ions between the interlayer spaces which decrease its expansiveness.

When water interacts with the clay minerals, Nelson et al. [47] argues that an intermolecular bonding develops due to the dipolar nature of water which causes ion hydration and adsorption of water on surfaces of clay particles by virtue of four simultaneous mechanisms including hydrogen bonding, cation hydration, osmosis, and dipole attraction. However, according to Labib and Nashed [51] and Akgün et al. [39], the stress equilibrium inside the clay-water mix is disturbed due to presence of $\mathrm{H}^{+}$and $\mathrm{OH}^{-}$in water because the clay particles carry negative edge charge and positive surface charge, which is responsible for the "expansive" movement. The magnitude of this movement is sometimes several degrees higher, and the theory of consolidation, moisture content, and suction-based techniques are used to predict the resulting movement [23].

\section{Damages Caused by Expansive Soils in Superstructures and Infrastructures}

The damage of expansive soils to lightly loaded civil engineering structures (pathways, highways, boundary walls, one to three storied buildings, water, and sanitation pipelines below the ground surface) is more significant due to large swelling pressure. The swelling phenomenon is complex and hazardous in nature, with $P_{\mathrm{s}}$ sometimes approaching to lifting up the foundation of structures and pavements, causing partial damage or entire destruction and monetary losses [52-54]. It has been established that almost 33\% of total land in Sudan, 20\% land area each in Indonesia and India, more than $12 \%$ of the Syrian land, and $6 \%$ land of China comprise arid regions with presence of expansive soils and/or black cotton soils [23, 41, 55-58]. The annual economic loss due to construction on expansive soils exceeds approximately nine billion US \$ in USA [59], one billion USA \$ in China [60], and USA \$ 0.5 billion in the UK [36]. In another study by Simons [11] and Zhao et al. [61], in USA, between 1970 and 2000, the total annual building loss due to expansive soil damages increased by $140 \%$ with cost of damages reaching USA $\$ 4.7$ billion. Also, $25 \%$ of all homes in the USA were affected by the expansive soil damages [41].

In many cases, for example, in parts of USA and Australia, the maintenance cost of roads built on expansive soils exceeds the cost of construction $[1,2,11]$. Dafalla and Shamrani [62] noted that if preliminary geotechnical investigation of expansive soils in subgrades of pavements is not carried out prior to construction, it may lead to improper drainage and premature structural failures. Puppala and Pedarla [63] stressed the need of utilizing ecofriendly and economical waste materials such as bagasse ash, which offers high strength and more durability, to build subgrades over expansive soils [64-67]. These swelling soils are also present in the Middle East and Gulf countries including Pakistan, Iran, India, Oman, and Saudi Arabia that largely affects the lightly loaded civil engineering structures [40, 68]. Figure 3 shows an overview of the damage to buildings, roads, and embankments across different countries.

If the expansive soils are not dealt properly, the cracks may propagate wider and deeper due to rapid moisture exit, as shown in Figure 4 . The cracks are minimized and localized when blending with CSM (calcium carbide residue, in this case) is done. The integrity of sample is also significantly increased by using a higher dose of prescribed stabilizer mix. However, the damage associated with the expansive soils is countless, widespread, and inevitable. Therefore, more studies are required to further explore the complex cracking mechanism in order to gain a real insight about their unknown hazardous behavior.

\section{Ca-Based Stabilizers in Limelight}

4.1. Stabilization of Expansive Soils Using CSM. The search for state-of-the-art potential stabilizing materials to deal with the problematic soils is always in progress. The reasons which draw the attention of geotechnical engineers to 
TABLE 1: Various classification and characterization criteria available in the literature for expansive soils using basic geotechnical tests.

\#1 on the basis of swelling [41]

\begin{tabular}{|c|c|c|c|c|c|}
\hline Swell potential & Total expansion & US customary (tsf) & $\begin{array}{l}\text { Swell pressure } \\
\text { SI units }(\mathrm{kPa}) \\
\end{array}$ & Metric units $\left(\mathrm{kg} / \mathrm{cm}^{2}\right)$ & Degree of expansion \\
\hline $0-1.5$ & $0-10$ & $<2.05$ & $<196$ & $<2$ & Low \\
\hline $1.5-5$ & $10-20$ & $2.05-4.1$ & $196-392$ & $2-4$ & Medium \\
\hline $5-25$ & $20-35$ & $4.1-7.2$ & $392-687$ & $4-7$ & High \\
\hline$>25$ & $>35$ & $>7.2$ & $>687$ & $>7$ & Very high \\
\hline \multicolumn{6}{|c|}{$\# 2$ on the basis of Atterberg limits [42] } \\
\hline Linear shrinkage & Shrinkage index & PI & LL & SL & Expansivity index \\
\hline $0-8 \%$ & $<25 \%$ & $<18 \%$ & $<35 \%$ & $<14 \%$ & Low \\
\hline $8-13 \%$ & $25-35 \%$ & $18-25 \%$ & $35-45 \%$ & $12-14 \%$ & Medium \\
\hline $13-18 \%$ & $35-50 \%$ & $25-35 \%$ & $45-60 \%$ & $10-12 \%$ & High \\
\hline$>18 \%$ & $>50 \%$ & $>35 \%$ & $>60 \%$ & $<10 \%$ & Very high \\
\hline
\end{tabular}

\#3 on basis of free swell ratio (FSR) [43]

FSR Soil expansivity

$<1 \quad$ Negligible

$1-5 \quad$ Low

1.5-2 Moderate

2-4 High

$>4 \quad$ Very high

Clay type

Dominant clay mineral

\#4 on the basis of liquid limit (LL)

LL Classification

$0-20 \% \quad$ No swell

20-35\% Low swell

35-50\% Medium swell

$50-70 \% \quad$ High swell

70-90\% Very high swell

\#5 U.S. Army Waterways Experiment Station (WES 1983)

\begin{tabular}{lcccc} 
Classification of potential swell & Swell potential (\%) & LL (\%) & PI (\%) & Soil suction $(\mathrm{kPa})$ \\
\hline Low & $<0.5$ & $<50$ & $<25$ & $<160$ \\
Marginal & $0.5-1.5$ & $50-60$ & $25-35$ & $160-430$ \\
High & $>1.5$ & $>60$ & $>35$ & $>430$
\end{tabular}

\#6 China Ministry of Construction (CMC 2004) [44]

Standard absorption M.C (\%) PI (\%)

$<2.5<<15$

$2.5-4.8 \quad 15-28$

Nonswelling

Kaolinite

Swelling and nonswelling

Swelling

Swelling

Swelling

Kaolinite and montmorillonite

Montmorillonite

Montmorillonite

Montmorillonite

$4.8-6.8$

28-40

Free swell value (\%)

Swell potential class

$>6.8$

$>40$

$<40$

$40-60$

60-90

Nonexpansive

Low

Medium

High

TABle 2: Mineralogical properties of basic clay minerals (kaolinite, illite, and montmorillonite).

\begin{tabular}{|c|c|c|c|c|c|c|c|}
\hline Clay mineral & Structure & $\begin{array}{l}\text { Interlayer bond/ } \\
\text { intensity }\end{array}$ & $\begin{array}{l}\text { Isomorphous } \\
\text { substitution }\end{array}$ & $\begin{array}{l}\text { Shrink- } \\
\text { swell }\end{array}$ & $\begin{array}{c}\text { CEC } \\
(\mathrm{meq} / 100 \mathrm{~g})\end{array}$ & LL (\%) & $K(\mathrm{~m} / \mathrm{s})$ \\
\hline \multirow{4}{*}{$\begin{array}{l}\text { Kaolinite (1:1 clay } \\
\text { mineral) }\end{array}$} & $\begin{array}{l}\text { Alternating sheets } \\
\text { of silica tetrahedron }\end{array}$ & \multirow{4}{*}{ Hydrogen, strong } & \multirow{4}{*}{ Low } & \multirow{4}{*}{ Very low } & \multirow{4}{*}{$3-15$} & \multirow{4}{*}{$30-75$} & \multirow{4}{*}{$10^{-5}-10^{-7}$} \\
\hline & \begin{tabular}{|l|} 
Alumina \\
\end{tabular} & & & & & & \\
\hline & Silica & & & & & & \\
\hline & $\begin{array}{l}\text { and alumina } \\
\text { octahedral sheets }\end{array}$ & & & & & & \\
\hline $\begin{array}{l}\text { Illite ( } 2: 1 \text { clay } \\
\text { mineral) }\end{array}$ & $\begin{array}{l}\text { Alternating sheets } \\
\text { of alumina } \\
\text { octahedral sheets }\end{array}$ & K-ion, moderate & Moderate & Low & $10-40$ & $60-120$ & $10^{-6}-10^{-8}$ \\
\hline \multirow{4}{*}{$\begin{array}{l}\text { Montmorillonite } \\
(2: 1 \text { clay mineral })\end{array}$} & Silica & \multirow{4}{*}{$\begin{array}{l}\text { Van der Waal, } \\
\text { very weak }\end{array}$} & \multirow{4}{*}{ High } & \multirow{4}{*}{$\begin{array}{l}\text { Very } \\
\text { high }\end{array}$} & \multirow{4}{*}{$29-150$} & \multirow{4}{*}{$\begin{array}{l}\text { Up to } \\
900\end{array}$} & \multirow{4}{*}{$10^{-7}-10^{-9}$} \\
\hline & Alumina & & & & & & \\
\hline & Silica & & & & & & \\
\hline & $\begin{array}{c}\text { between two } \\
\text { silica tetrahedrons }\end{array}$ & & & & & & \\
\hline
\end{tabular}




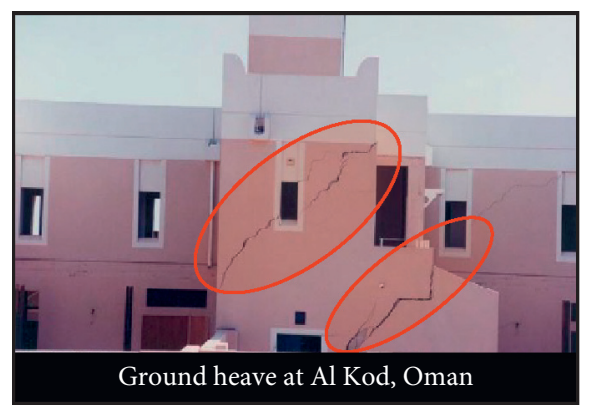

Swell pressure causes diagonal cracking in 2-storey building

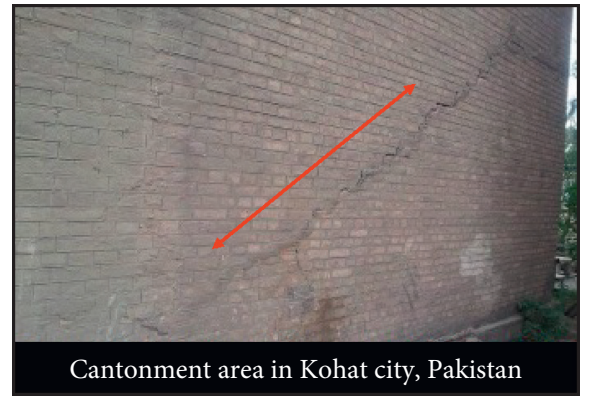

The wall is recorded to repeatedly crack after reconstruction

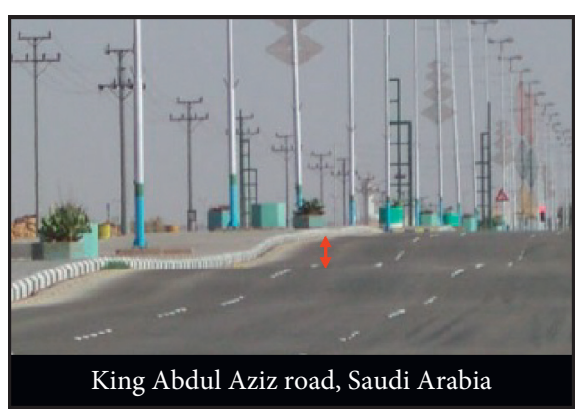

Uplifting of flexible pavement due to expansive soil

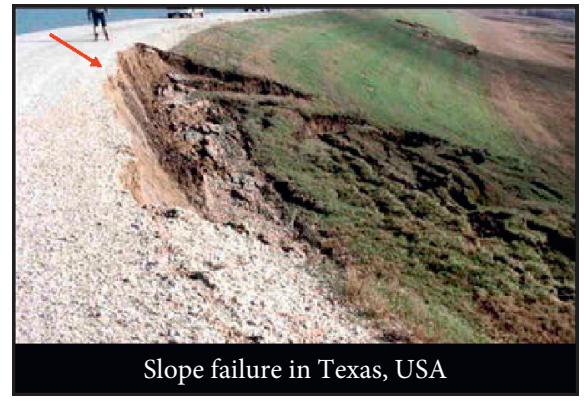

Expansive soils cause slope failure of embankment

Figure 3: Expansive soil damage to civil engineering infrastructure across Oman, KSA, Pakistan, and USA (with some changes for comparison purpose) $[62,69-71]$.
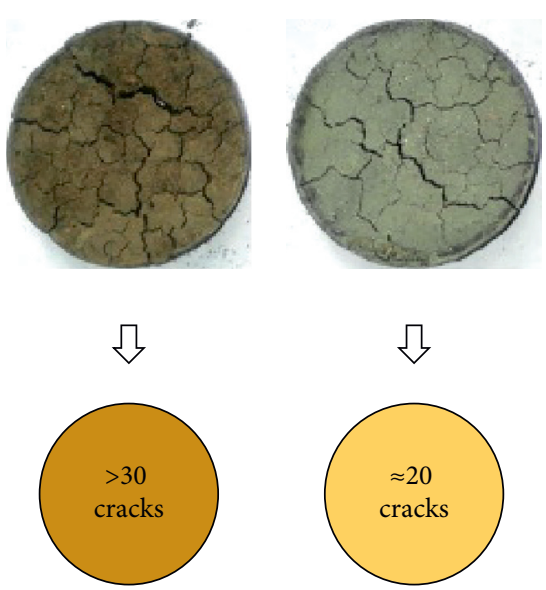

(a)

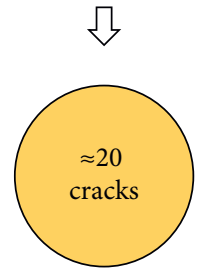

(b)
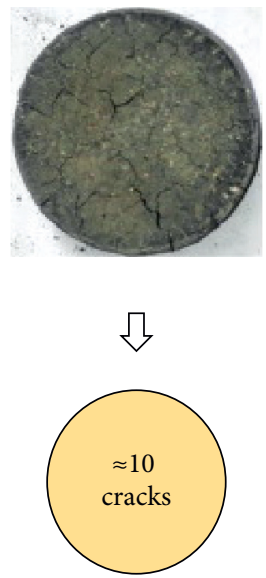

(c)
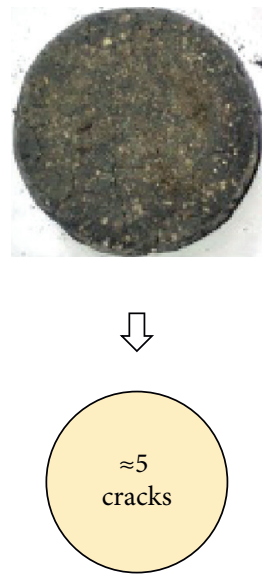

(d)

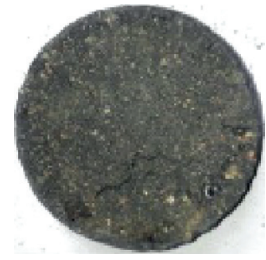

凸

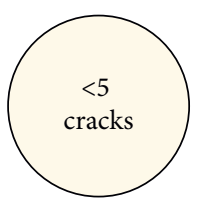

(e)

Figure 4: Morphology of cracks in expansive soil ( $\mathrm{LL}=77.6 \%, \mathrm{PI}=40.7 \%, \mathrm{MDD}=1.47 \mathrm{~g} / \mathrm{cm}^{3}$, and $\mathrm{OMC}=28 \%$ ) after blending with several mixtures of calcium carbide residue (CCR) and rice husk (RHA) and cured for 28 days [72].

employ CSM are as follows: (1) the replacement with coarse grained materials may be uneconomical because the expansive soil layers are extended deep and in irregular pattern, (2) the presence of $\mathrm{Ca}^{2+}$ ions speeds up the pozzolanic reactions [63] and tends to decrease the $P_{s}$, (3) it is a hot topic and is widely practiced in field nowadays, (4) the prewetting technique among other takes higher time (several years) for soils with low hydraulic conductivity [73], and (5) recycling gains environmental and economic benefits by reducing the usage of natural resources which leads to development of low-emission and low-energy technologies
[74]. The stabilizing materials with $\mathrm{Ca}^{2+}$ lower down the $P_{\mathrm{s}}$ by two mechanisms: (1) by stabilizing the structure of clay particles using cation exchange and (2) by increasing the concentration of cations held between soil within water and thus depleting the double layer thickness [72].

4.2. Characteristics of CSM. A large number of CSMs, for instance, lime, cement, fly ash (FA), ground-granulated blast furnace slag (GGBS), bagasse ash (BA), cement kiln dust (CKD), rice husk ash (RHA), silica fume [64], steel slag (SS), 
TABLE 3: Summary of oxide composition of traditional Ca-based stabilizer materials (CSMs) from previous studies.

\begin{tabular}{|c|c|c|c|c|c|c|c|c|c|c|c|}
\hline Popular Ca-based stabilizers & $\mathrm{CaO}(\mathrm{C})$ & $\mathrm{SiO}_{2}(\mathrm{~S})$ & $\mathrm{Al}_{2} \mathrm{O}_{3}(\mathrm{~A})$ & $\mathrm{SO}_{3}$ & $\mathrm{Fe}_{2} \mathrm{O}_{3}$ & $\mathrm{MgO}$ & $\mathrm{K}_{2} \mathrm{O}$ & $\mathrm{TiO}_{2}$ & LOI & $G_{\mathrm{s}}$ & LL $(\%)$ \\
\hline Hydrated lime [84] & 70.9 & 1.20 & 0.70 & - & 0.10 & 0.50 & 0.10 & 0.10 & 26.1 & 2.32 & \\
\hline Extinct lime [85] & 83.3 & 2.50 & 1.50 & 2.50 & 2.00 & 0.50 & - & - & - & - & - \\
\hline Lime $[86]$ & 45.0 & 12.0 & 1.20 & 0.00 & 0.50 & 0.70 & 0.80 & - & 40.0 & - & - \\
\hline Lime sludge [87] & 48.0 & 6.50 & 1.15 & - & 1.20 & - & - & - & - & - & - \\
\hline Cement $[88]$ & 44.7 & 27.4 & 13.1 & 3.96 & 3.30 & 1.19 & 1.14 & - & 4.01 & - & - \\
\hline Cement [89] & 65.2 & 20.4 & 4.10 & & 3.20 & 4.50 & 0.59 & - & - & - & - \\
\hline Cement [90] & 63.0 & 20.0 & 6.00 & 2.00 & 3.00 & - & 1.00 & - & - & - & - \\
\hline CKD [91] & 63.9 & 11.9 & 9.90 & 0.00 & 3.40 & 1.70 & 0.10 & - & 4.70 & 2.80 & \\
\hline FA [92] & 1.60 & 54.4 & 28.6 & - & 3.20 & 1.40 & 1.70 & 1.80 & 5.00 & 2.15 & 32 \\
\hline FA [93] & 2.40 & 58.5 & 27.8 & 0.03 & 8.10 & 0.70 & 0.01 & - & 2.10 & - & - \\
\hline FA [94] & 6.70 & 55.6 & 26.4 & - & 3.90 & 0.60 & 2.10 & 1.00 & 3.68 & 2.13 & 46 \\
\hline FA [95] & 1.60 & 54.4 & 28.6 & - & 3.20 & 1.40 & 1.70 & 1.80 & 5.00 & 2.15 & 32 \\
\hline FA [96] & 48.9 & 19.9 & 9.30 & 7.30 & 5.70 & 3.70 & 0.50 & - & 3.01 & - & - \\
\hline Class C FA [97] & 29.1 & 31.9 & 17.5 & 2.0 & 5.10 & - & - & - & 1.00 & 2.6 & NP \\
\hline Class F FA [98] & 14.3 & 41.3 & 16.3 & 0.70 & 6.30 & 4.70 & 2.60 & - & 0.10 & 2.53 & NP \\
\hline GGBS [99] & 34.0 & 34.3 & 17.9 & 1.64 & 1.00 & 6.02 & 0.64 & - & 2.66 & - & - \\
\hline GGBS [100] & 44.9 & 29.2 & 13.8 & - & 5.50 & 6.20 & 1.00 & 2.10 & - & 2.84 & 40 \\
\hline Steel slag $[100]$ & 25.8 & 16.4 & 2.40 & - & 26.0 & 10.0 & - & 0.80 & - & - & - \\
\hline BA [91] & 11.7 & 47.8 & 10.2 & - & 5.70 & 2.80 & 2.60 & 0.80 & 16.1 & - & - \\
\hline $\mathrm{BA}[95]$ & 3.20 & 57.1 & 29.7 & 0.02 & 2.75 & - & - & 1.13 & - & - & - \\
\hline BA $[101]$ & 4.30 & 67.8 & 6.90 & - & 3.84 & - & - & - & - & - & - \\
\hline Coal waste ash (CWA) [102] & 2.30 & 55.7 & 23.3 & - & 3.40 & 0.90 & 3.50 & 1.20 & 38.7 & 1.94 & - \\
\hline GSA [93] & 10.9 & 33.4 & 6.8 & 6.40 & 2.16 & 4.72 & 25.4 & - & - & - & - \\
\hline GSA [103] & 15.5 & 23.9 & 8.9 & 5.7 & 5.2 & 6.9 & 22.9 & 1.02 & - & - & - \\
\hline
\end{tabular}

LOI: loss on ignition; $G_{s}$ : specific gravity; NP: nonplastic; —, "no available data."

sewage sludge ash (SSA), palm oil fuel ash (POFA), fuel oil fly ash (FOFA), groundnut shell ash (GSA) [12, 34, 75-78], are employed in geotechnical engineering. Some "nanomaterials" rich in Ca content [79] also act as CSM, and Sabat [80] suggested these could be used for strength enhancement, plasticity reduction, and limiting swell and shrinkage strains. Also, the mixture of cement, emulsion, and water forms evolutive materials such as cold recycled mixtures (CRMs), which are responsible for the long-term properties in the pavement construction [81-83].

The different CSMs with chemical compositions determined using X-ray fluorescence (XRF) are listed in Table 3. The widely used CSMs are lime $(\mathrm{CaO} \approx 40-50 \%$ and $70-80 \%)$, cement $(\approx 40-50 \%$ and $60-70 \%)$, FA $(<10 \%$ and $30 \%-50 \%)$, GGBS $(\approx 30-50 \%)$, and BA $(<5 \%$ and $10-20 \%)$. The availability of surplus $\mathrm{Ca}^{2+}$ tends to replace the monovalent sodium or hydrogen ions rapidly especially in a high $\mathrm{pH}$ environment, which gives a higher volumetric stability to expansive soils through ion exchange. This leads to the flocculation reaction, which in turn improves the physical and mechanical behavior of the soil and increases the soil strength.

However, calcium carbonate $\left(\mathrm{CaCO}_{3}\right)$ is produced due to carbonation of lime which is a source of weakness due to its plastic nature which increases the plasticity of expansive soils [23]. Modarres and Nosoudy [87] stated that $\mathrm{CaCO}_{3}$ formation is related to presence of excess lime and the unavailability of the reactive $\mathrm{SiO}_{2}$ and $\mathrm{Al}_{2} \mathrm{O}_{3}$.

The advantages and disadvantages of CSMs are briefly summarized in Table 4, which serves as a guide to deal with CSM stabilization of expansive clays, on-site commercially and in the laboratory for research.

\section{Effect on Geotechnical Properties with Emphasis on Chemical Processes and Microstructure Interaction}

5.1. Main Effect of Lime Stabilization. Lime stabilization improves the geotechnical properties by changing the microstructure and fabric of expansive clays [112] through four important reactions [113], i.e., (1) cation exchange, (2) flocculation-agglomeration, (3) carbonation, and (4) pozzolanic reaction. It is mainly due to the flocculation-agglomeration reaction that the geotechnical properties of high plasticity clay soils are improved. Because of flocculation, the PI and FSI lower down, whereas compression strength and permeability go up $[23,114-116]$. Figure 5 shows that, with lime treatment, the PI reduces by six times the original and transforms from $\mathrm{CH}$ to $\mathrm{ML}$ showing the efficacy of lime stabilization. The presence of kaolinite, illite, and Mt affects the final stabilization and highly governs the stabilizer characteristics, such as dosage methodology, strength gain, engineering conditions, and curing condition effect [23].

The period of curing is an important parameter in achieving long-term compressive $\left(q_{u}\right)$ and split tensile strength $\left(q_{t}\right)$, as the pozzolanic reaction progresses towards completion $[54,63,117]$. The strength gain with $4 \%$ lime and curing at 28 days for quartz, kaolinite, and $\mathrm{Mt}$ were recorded as $330 \%, 230 \%$, and $130 \%$, respectively, in contrast to samples with $4 \%$ lime and tested after one day curing [118]. Increased curing duration is an effective approach in reducing the swell potential of expansive soils treated with lime. At same water content in the modified compaction test, an increase of $133 \%$ in UCS is observed 
TABLE 4: Summary of advantages and disadvantages of calcium-based stabilizer materials (CSMs).

\begin{tabular}{l}
\hline Stabilizer \\
\hline (i) Long-term strength is achieved as a result \\
of pozzolanic reaction which is time-
\end{tabular}
dependent and lasts for longer duration.

(ii) Lime-treated soils undergo immediate modification resulting in a relatively denser microstructure and higher strength.

Ca based materials (CSMs): lime

[12, 104-106], cement [107], FA [12, 24], SF [108], GGBS [109], BA [76, 110], CCR [72], POFA [111], GSA [93] (iii) In viewpoint of economy, usually small amount of material is required as compared with non-CSMs.

(iv) The rate of strength gain is much higher and faster in soil stabilized using cement.

(v) The PI reduction by lime is the highest for problematic Mt. Alternatively, using quicklime due to its elevated reaction temperature enables stabilization in cold regions.

(vi) The most commonly used materials comprising aluminosilicates include GGBS and fly ash.
Disadvantages

(i) The release of deleterious substances contaminate the underground water. The "ultimate" strength gain reaches several years.

(ii) These cause adverse environmental and economic concerns by vast $\mathrm{CO}_{2}$ emissions. At early modification stages, lime makes the soil less dense.

(iii) The variation in site conditions with those simulated in a laboratory often leads to marginal errors.

(iv) The brittle failure is undesirable with respect to structural stability.

(v) The effect of lime modification in clays containing quartz is almost negligible due to the increased period of curing is essential.

(vi) Class F fly ash contains low calcium and thus requires an activator in order to be used as the stabilizer material.

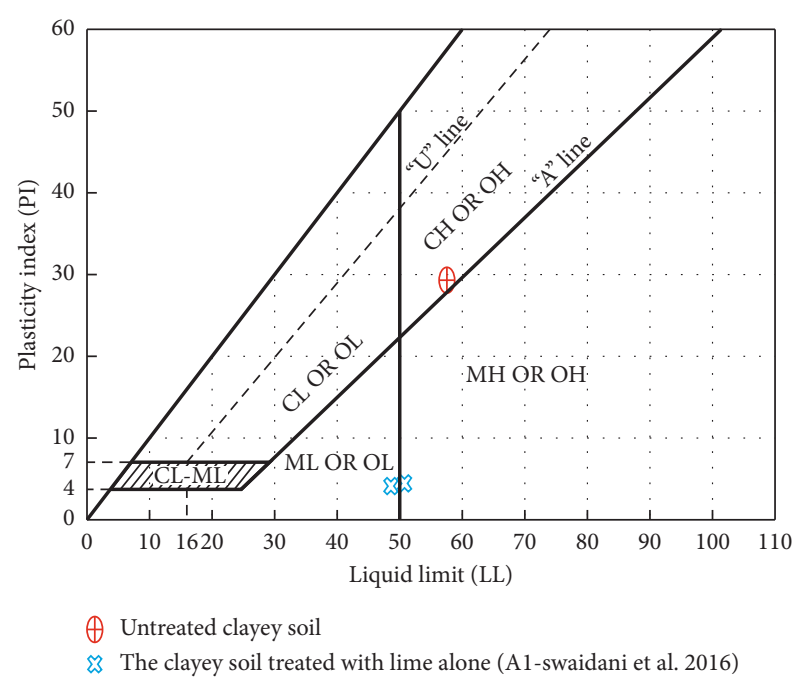

FIGURE 5: The main and interaction effects of lime in comparison with untreated soil, on Casagrande's plasticity chart (with some modifications in the original figure) [112].

for cement-treated samples cured from 7 days to 28 days [119]. Ali and Zulfiqar [114] remarked that this behavior is due to the replacement of hydrated lime $\mathrm{Ca}(\mathrm{OH})_{2}$ with quicklime $\mathrm{CaO}$ at earlier days, which in turn intensifies the pozzolanic reaction. This observation was also depicted from their test results.

According to Idris and El-Zahhar [120], the microstructural properties (surface features, size, and shape) of the sampled particles of lime stabilized soil are highly dependent on the curing period. Scanning electron microscopy (SEM) determines the effect of stabilizer treatment on morphological structure with magnifications at micrometer scale. Also, by the virtue of chemical analysis, SEM assists in evaluating the calcium localization on clay particles [118].
The SEM micrographs in Figure 6 show a variety of samples were stabilized with $8 \%$ lime and ( $20 \%$ pozzolan $+8 \%$ lime) blend, respectively, and upon 7 days curing, the particles of clay soils become coarser at microlevel. The $8 \%$ lime treatment contains coarse soil matrix, illustrated in Area 3, and is attributed to plasticity reduction.

It is important to determine how efficient lime acts when it is used as a potential CSM. The suitability of lime in silicarich soils, soil containing gypsum, sulfate-rich soils, and $\mathrm{Fe}_{2} \mathrm{O}_{3}$-rich soils is briefly discussed. In order to analyze the efficacy of lime as the stabilizer material, the ratio between lime: silica, lime: alumina, and lime: (silica + alumina), for the poststabilization samples, must be greater. The over dosage of lime is more indicative in $\mathrm{SiO}_{2}$-rich soils, where the formation of highly porous silica gel takes place. So, the strength is substantially undermined due to cementation as the excess gel is porous and has a high water holding capacity. Therefore, it contributes to an overall strength loss and results in higher plasticity and swell potential. In their study on soils containing gypsum, lime treatment of $3 \%$ was found as optimum for strength requirement, and thereafter, the effect reversed [121]. In addition, Shi [122] stated that, for $\mathrm{SO}_{4}$-rich soils, the unavailability of hydrated $\mathrm{CaO}$ makes lime a weaker choice too. A variety of soils with large contents of $\mathrm{Fe}_{2} \mathrm{O}_{3}$ and lime exhibits poor dispersibility, and the particle-to-particle bonding is improved, which aids in restraining both the FS and $P_{\mathrm{s}}$ [115]. Thus, it can be inferred that lime stabilization of expansive soils ranging from low to high characterization mainly depends on type of clay minerals and environment of lime-soil reactions.

\subsection{Main Effect of Cement and Interaction Effect with Lime.} The ordinary Portland cement (OPC) is the "key material" to housing and infrastructure worldwide which is also employed in soft ground stabilization. But its use is 


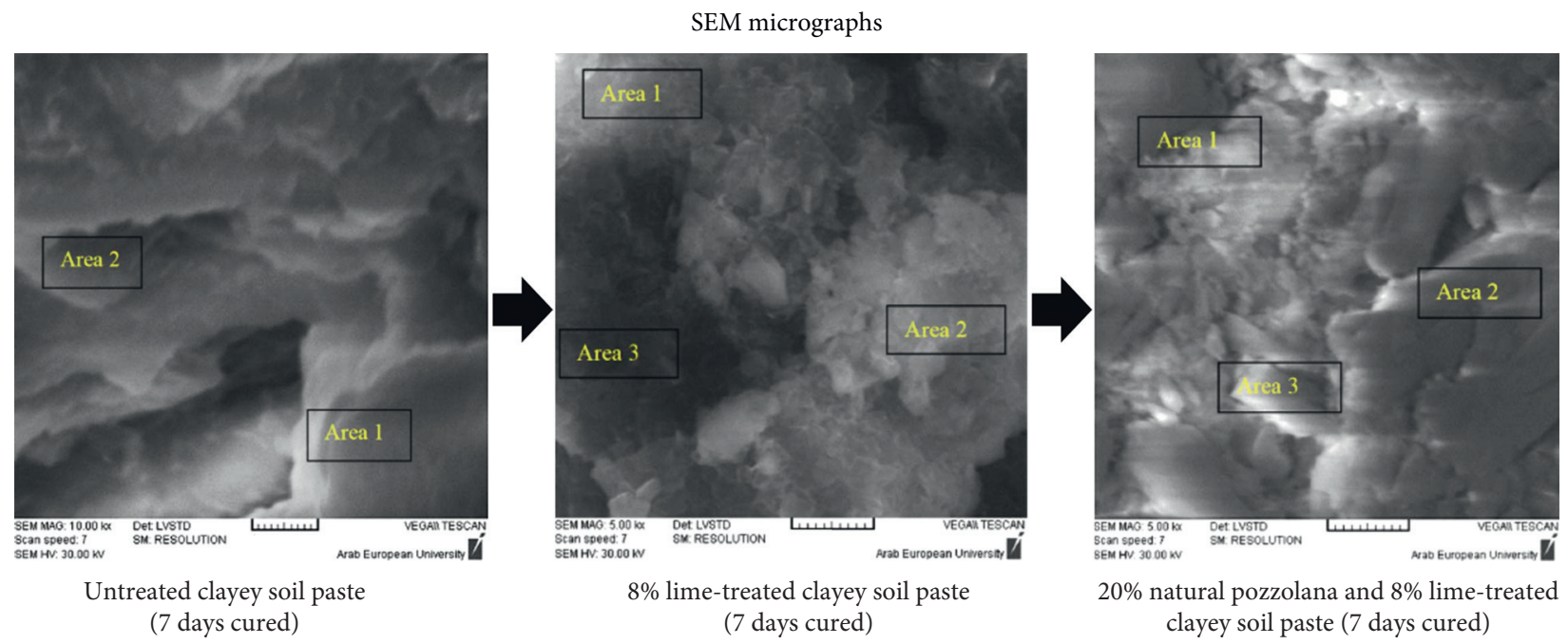

Figure 6: Microstructural comparison of clay soil paste cured at 7 days (untreated sample, treated with $8 \%$ lime, treated with $20 \%$ pozzolan $+8 \%$ lime) (modified after [54]).

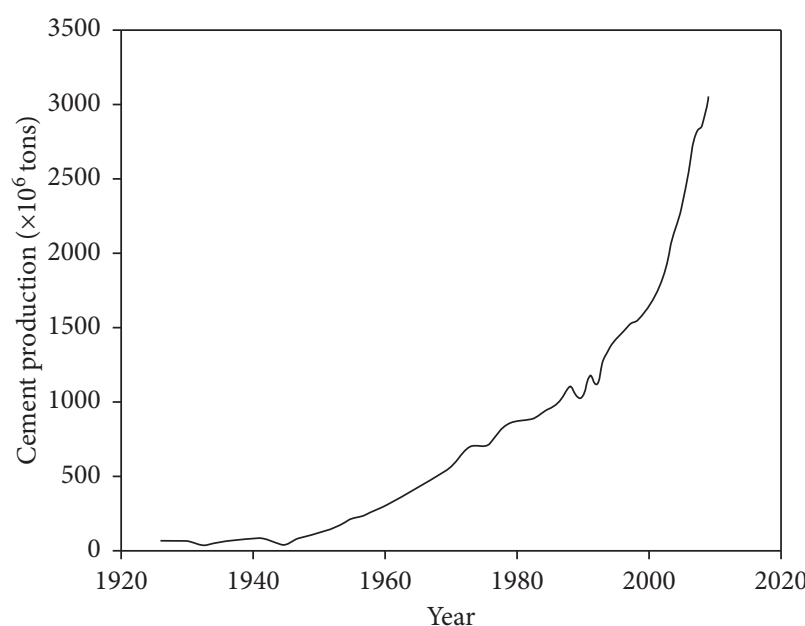

(a)

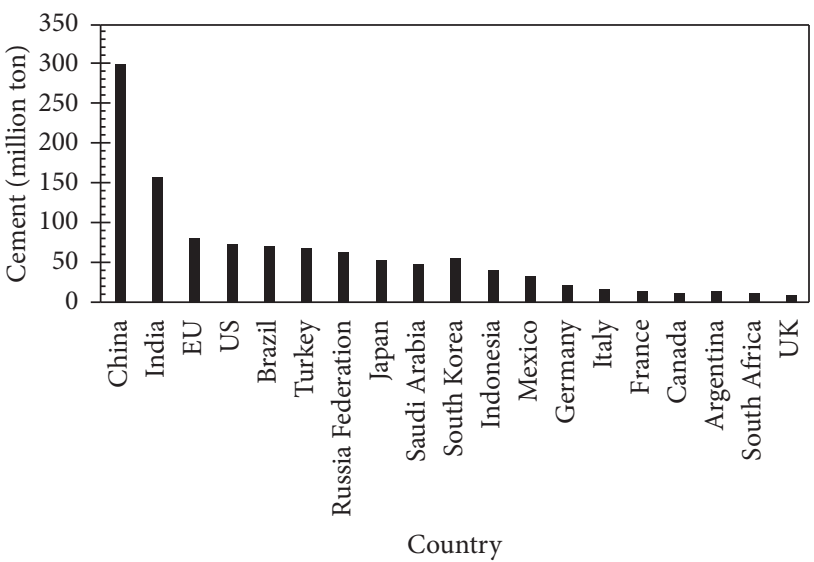

(b)

FIGURE 7: Global annual cement production: (a) between 1925-2009 [124]; (b) in different countries [125].

somehow restrained since global warming and rapidly changing climate are challenging global issues of today's world $[22,123]$. Figure 7 indicates the global annual cement production between 1925 and 2009 and the cement production in various countries with China taking the lead as it plans to construct 40 billion square meters of floor space until 2036.

Cement stabilization is specifically recommended and significantly increases the cohesion, strength, and durability of coarse-graded mixtures having a low PI [126]. Zaimoglu [127] refrained the use of cement owing to its high cost and hazardous nature. Cement and lime stabilization are more or less identical in yielding results with respect to mechanism of modification since the formation of C-S-H and C-A-H takes place in both cases which form cementitious links with the untreated clay particles. Lime and cement have their own benefits and ill effects regarding the viewpoint of stabilizing materials.
The effect of cement alone on the geotechnical properties and engineering characteristics is reviewed first. Cement modifies the physical properties of certain waste materials (e.g., marble industrial waste and bottom ash) and decreases their toxicity level [128-130]. The plasticity and swell indices lower down, thereby increasing the shear strength parameters and permeability characteristics. Based on results from past literature, it is illustrated from Figure 8 that, up to $10 \%$ addition of cement and lime each, both $P_{\mathrm{s}}$ and FS values are reduced considerably. The $P_{\mathrm{s}}$ is necessary to evaluate the nature of problem associated with expansive problems. So, in order to study the effect of stabilizers on $P_{\mathrm{s}}$, almost all curves record to follow similar declining trend, from 500 to $700 \mathrm{kPa}$, for untreated soil to 170 to $300 \mathrm{kPa}$, for both lime and cement (10\% dosage each), with the least amount of variance between lime and cement [71]. The significant reduction in maximum $P_{\mathrm{s}}$ is observed in the data of Vijayvergiya and Ghazzallay in contrast to almost identical 

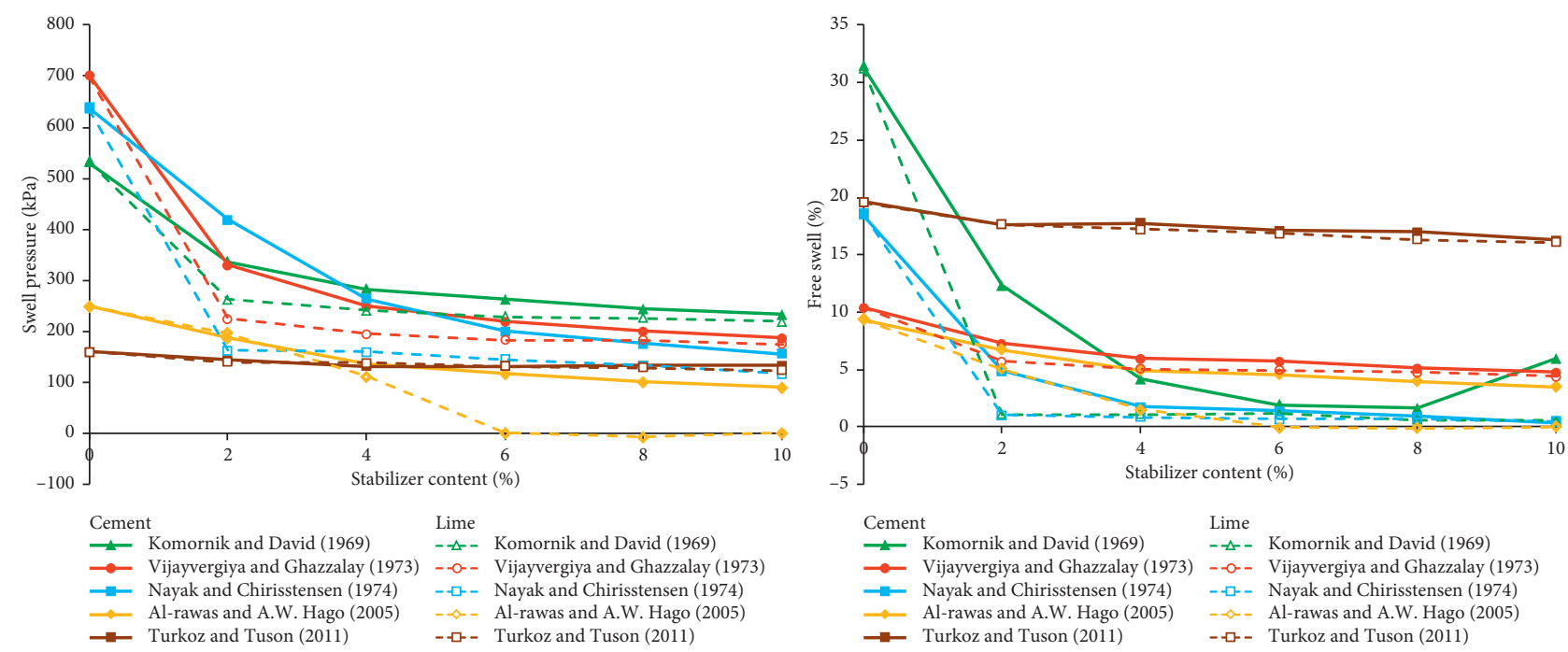

Figure 8: Main effect of both cement and lime on the plot of swelling pressure and free swell, from past literature.

values reported by Turkoz and Tuson [131], when considering the initial and final $P_{\mathrm{s}}$ values on each curve. On the contrary, the treatment of lime and cement within range of 2 to $10 \%$ dosage level indicates that FS curves experience wide variance. The trend shown by Komornik and David is most significant, witnessing almost 6 times reduction among untreated and highest dosage values, in contrast to results obtained by Turkoz and Tuson which changes from $20 \%$ to merely $15 \%$. Moreover, the remaining three curves for lime and cement are seen to follow a similar trend which illustrates an intermediate effect on the reduction of FS values. Lastly, it can be seen in Figure 8 that the stabilization mechanism of lime and cement for each specified treatment resembles each other, with cement proving to be more effective in terms of minimizing the swell. Note that, by using 9\% lime alone, the $P_{\mathrm{s}}$ becomes zero and the effect on plasticity value is almost the same as recorded for the case of lime-cement mix [132].

The CKD is fine-grained powder-like dust material obtained as a by-product from the manufacturing of cement [133]. It contains traces of reactive $\mathrm{CaO}$ and alkaline compounds and is therefore highly fine to be used as the effective soil stabilizing agent. However, the properties of CKD largely differ depending upon the manufacturing plant, cement kiln type, and the characteristics of raw materials employed in cement production $[12,134,135]$. Its production is estimated to be approximately 30 million tons per year, across the globe, of which $80 \%$ causes an environmental threat and is not safely disposed [97]. Many researchers have suggested its use as potential stabilizer for clayey soils. The (volcanic ash $+20 \%$ CKD) stabilizer mix will yield a significant improvement in mechanical properties [136] and pronounced increase in CBR values (above 80\%); therefore, $\mathrm{Yu}$ et al. [91] found it suitable for the construction of economical building units and small-scale roadways.

In terms of the final stabilization effects, the interaction effect of cement with lime is more efficacious than lime or cement alone treatment [116]. The PI decreases by $60 \%$, and the $P_{\mathrm{s}}$ drops by $82 \%$ when ( $5 \%$ lime $+3 \%$ cement) blend is used to modify medium expansive soil extracted from depth [71]. The $P_{\mathrm{s}}$ value is recorded to decrease from $249 \mathrm{kPa}$ for untreated soil to $45 \mathrm{kPa}$ for ( $5 \%$ lime $+3 \%$ cement) blend. Their combined effect on geotechnical properties is also summarized succinctly in Table 5 .

Recently, it is found that recycled cement can be yielded by burning old OPC pastes at elevated temperatures of $450^{\circ} \mathrm{C}$ (RC-450), which will lower down the $\mathrm{CO}_{2}$ emission by $94 \%$, attaining an equivalent strength of OPC. It is obvious from surface morphology studies by SEM that $\mathrm{CO}_{2}$ is reduced by (1) formation of calcium carboaluminate and (2) C-S-H gels containing calcite, as both are evidenced in the SEM micrographs in Figures 9(a) and 9(b), and in the EDX analyses in Figures 9(c) and 9(d), respectively. In the plots between energy on abscissa and counts on ordinate, the peaks for only calcite, silica, and alumina are shown with almost no traces of other problematic clay minerals $[94,144]$. Figures 9(a) and 9 (b) also reveal the formation of portlandite and ettringite with a honey-combed structure in the micrograph of OPC being transformed into a denser structure with newly formed carboaluminate at $4 \mu \mathrm{m}$ magnification level. It is therefore to say that RC-450 (1) is richer in calcium carbonate amount, (2) has densely arranged nanoparticles, and (3) has no portlandite content. Kolias et al. [99] delineated that tobermorite formation leads to a denser and stable soil structure.

The thermogravimetric analysis (TGA) measures change in mass of a material as a function of either temperature or time and is capable to quantify phase compositions in ettringite, portlandite, gehlenite, and calcite [145]. The results of TGA in Figure 9(e) show that $\mathrm{CO}_{2}$ fixation (that is to combat the challenge of global warming [146]) in case of RC450 is low (75\%) in contrast with that of a higher value for OPC (87\%) at same temperature. The trend of reducing weight loss with temperature thus signals a low $\mathrm{CO}_{2}$ fixation value for RC-450. This shows the significant effect of recycled 
TABle 5: A succinct list of research conducted on Ca-based stabilizer materials for different expansive soils across the world.

\begin{tabular}{|c|c|c|c|c|c|c|c|c|c|c|c|}
\hline \multirow[b]{2}{*}{$\begin{array}{l}\text { Location of } \\
\text { expansive soil }\end{array}$} & \multirow[b]{2}{*}{$G_{\mathrm{s}}$} & \multicolumn{7}{|c|}{ Expansive soil properties } & \multicolumn{2}{|c|}{ Stabilizer } & \multirow[b]{2}{*}{ Properties improved } \\
\hline & & $\begin{array}{l}\mathrm{LL} \\
(\%)\end{array}$ & $\begin{array}{l}\mathrm{PL} \\
(\%)\end{array}$ & $\begin{array}{c}\text { PI } \\
(\%)\end{array}$ & Activity & USCS & $\underset{\left(\mathrm{kN} / \mathrm{m}^{3}\right)}{\mathrm{MDD}}$ & $\begin{array}{c}\mathrm{OMC} \\
(\%)\end{array}$ & Type & $\begin{array}{c}\text { Optimum } \\
\text { amount }\end{array}$ & \\
\hline $\begin{array}{l}\text { Oman, Al- } \\
\text { Khoud [71] }\end{array}$ & 2.80 & 50 & 29.5 & 20.5 & 1.03 & $\mathrm{MH}$ & 17.5 & 21 & $\begin{array}{l}\text { Lime }(\mathrm{L}), \\
\text { cement }(\mathrm{C}), \\
\text { pozzolan }(\mathrm{P})\end{array}$ & $\begin{array}{c}5 \% \mathrm{~L}+3 \% \mathrm{C} \text {. } \\
\text { Other studies: } \\
2 \% \mathrm{~L}+1 \% \mathrm{C} \\
{[94]} \\
4 \% \mathrm{~L}+30 \% \mathrm{red} \\
\text { mud }[137] \\
8 \% \mathrm{~L}+4 \% \mathrm{C} \\
{[71]} \\
8 \% \mathrm{~L}+20 \% \mathrm{P} \\
{[84]}\end{array}$ & $\begin{array}{c}P_{\mathrm{s}} \downarrow=249 \text { to } 45 \mathrm{kPa} \\
\mathrm{PI} \downarrow=20 \text { to } 8 \% \\
P_{\mathrm{s}} \downarrow=\text { by } 840 \%\end{array}$ \\
\hline $\begin{array}{l}\text { China, Hefei, } \\
\text { Anhui [138] }\end{array}$ & 2.71 & 42.8 & 22 & 20.8 & - & $\mathrm{MH}$ & 17.3 & 18.9 & $\begin{array}{l}\text { Fly ash }(\mathrm{F}) \text {, } \\
\text { sand }(\mathrm{S}) \text {, } \\
\text { basalt fiber } \\
\text { (B) }\end{array}$ & $\begin{array}{c}10 \% \mathrm{~F}+8 \% \\
\mathrm{~S}+0.4 \% \mathrm{~B}\end{array}$ & $\begin{array}{c}\mathrm{LL} \downarrow, \mathrm{PI} \downarrow, \mathrm{PL} \uparrow \mathrm{UCS} \\
\uparrow=345 \text { to } 900 \mathrm{kPa} \text { (with } \\
0.4 \% \text { Ba fibers) }\end{array}$ \\
\hline $\begin{array}{l}\text { USA, Idabel, } \\
\text { Oklahoma [121] }\end{array}$ & - & 79 & 25 & 54 & 1.30 & $\mathrm{CH}$ & - & - & $\begin{array}{l}\text { Lime (L) and } \\
\text { Class C fly } \\
\text { ash (CFA) }\end{array}$ & $\begin{array}{c}5,10,15, \text { and } \\
20 \%[54] \\
\text { L and CFA each }\end{array}$ & $\begin{array}{c}\text { Shrinkage } \downarrow=\text { maximum } \\
\text { at } 20 \% \text { lime }\end{array}$ \\
\hline $\begin{array}{l}\text { India, Calcutta } \\
(80 \% \mathrm{BC}+20 \% \\
\text { Na-bentonite }) \\
{[95]}\end{array}$ & 2.66 & 78 & 45 & 33 & 3 & $\mathrm{CH}$ & - & - & $\begin{array}{l}\text { Fly ash (F) } \\
\text { and GGBS } \\
\quad(G)\end{array}$ & $\begin{array}{c}20 \% \text { mixture of } \\
\text { F and G [121] } \\
(\mathrm{F}: \mathrm{G} 70: \\
30)+1 \% \mathrm{~L} \\
25 \% \mathrm{~B} \text { (modest }\end{array}$ & $\begin{array}{c}\mathrm{UCS} \uparrow=270 \text { to } 450 \mathrm{kPa} \\
(28 \text { days curing) } \\
\text { Addition of } 1 \% \\
\text { Lime: } 270 \text { to } 875 \mathrm{kPa}\end{array}$ \\
\hline $\begin{array}{l}\text { Australia, } \\
\text { Queensland [68] }\end{array}$ & 2.65 & 86 & 37 & 49 & 1.66 & $\mathrm{CH}$ & 12.65 & 36.5 & $\begin{array}{l}\text { Bagasse ash } \\
\text { (B) and lime } \\
\text { (L) }\end{array}$ & $\begin{array}{c}\text { effect on } \\
\text { strength) } \\
10 \% \mathrm{~B}+10 \% \mathrm{~L} \\
{[95]}\end{array}$ & $\begin{array}{c}\text { MDD } \downarrow \text {, swelling } \downarrow \\
\text { UCS } \uparrow(0-25 \% \text { BA + lime } \\
\text { mix })\end{array}$ \\
\hline $\begin{array}{l}\text { Pakistan, Kohat } \\
\text { city, KPK [139] }\end{array}$ & 2.71 & 43 & 41 & 22 & 0.6 & CL & 18.1 & 14.9 & $\begin{array}{l}\text { Bagasse ash } \\
\text { (B) and } \\
\text { marble dust } \\
\text { (M) [68] }\end{array}$ & $\begin{array}{c}4-6 \% \mathrm{~B} \\
\text { 8-10\% M [140] } \\
\text { Combined effect: } \\
\text { 8\% B + 16\% lime } \\
\text { sludge [139] }\end{array}$ & $\begin{array}{c}\text { B: swelling } \downarrow, \mathrm{UCS} \uparrow \\
\text { till 5\% B, MDD } \mathrm{M}_{5 \%} \uparrow \\
\text { M: swelling } \downarrow \text {, UCS } \uparrow \\
\text { At } 10 \% \mathrm{M}, \mathrm{MDD}_{4 \%} \uparrow\end{array}$ \\
\hline $\begin{array}{l}\text { India, Dadri } \\
(100 \% \\
\text { bentonite) Dadri } \\
{[96]}\end{array}$ & 2.71 & 412 & 60 & 352 & 3.5 & $\mathrm{CH}$ & 12.6 & 41.0 & $\begin{array}{l}\text { Dadri fly ash } \\
\text { and lime (L) }\end{array}$ & $\begin{array}{c}10-15 \%[141] \\
\text { (with 3\% L) }\end{array}$ & $\begin{array}{c}\text { UCS } \uparrow \text { (strength of cured } \\
\text { sample }>\text { uncured } \\
\text { samples) } \\
P_{\mathrm{s}}=\downarrow \text { (as F and L content } \\
\text { increases) }\end{array}$ \\
\hline $\begin{array}{l}\text { China, Guangxi } \\
\text { province }[14]\end{array}$ & 2.73 & 77 & 34 & 43 & - & $\mathrm{CH}$ & 17.2 & - & $\begin{array}{l}P_{s} \text { versus } \omega \text {, } \\
\text { MDD } \\
\text { relation }\end{array}$ & - & $\begin{array}{l}\text { Models developed which } \\
\text { needs to be validated due } \\
\text { to lack of experimental } \\
\text { results }\end{array}$ \\
\hline $\begin{array}{l}\text { Algeria, S-H } \\
\text { clay, M'sila [142] }\end{array}$ & - & 84 & 33 & 51 & 1.98 & $\mathrm{CH}$ & 19.7 & 19.43 & $\begin{array}{c}\text { Portland } \\
\text { cement }(\mathrm{P}) \\
\text { and lime }(\mathrm{L})\end{array}$ & $\begin{array}{l}12 \% \mathrm{P} \text { and } \mathrm{L} \\
\text { each. (lime is a } \\
\text { much better } \\
\text { option) }\end{array}$ & $\begin{array}{c}\text { PI: } \downarrow \text {, methylane blue } \\
\text { values } \uparrow, \mathrm{CBR} \downarrow \text {, shear } \\
\text { strength } \uparrow\end{array}$ \\
\hline $\begin{array}{l}\text { Iran, taleghan } \\
\text { city [87] }\end{array}$ & - & 47 & 21 & 26 & $<1$ & CL & 16.4 & 18.0 & $\begin{array}{l}\text { Coal ash }(\mathrm{C}) \\
\text { and hydrated } \\
\text { lime }(\mathrm{HL})\end{array}$ & $9 \% \mathrm{C}+6 \% \mathrm{HL}$ & $\begin{array}{c}\text { With coal: less effect on } \\
\text { properties } \\
\text { coal }+ \text { h. lime, UCS } \uparrow \\
\text { PI } \downarrow, \text { CBR } \uparrow\end{array}$ \\
\hline $\begin{array}{l}\text { Taiwan, taipei } \\
{[137]}\end{array}$ & - & 30 & 20 & 10 & $>1$ & $\mathrm{CL}$ & 16.6 & 16.8 & $\begin{array}{c}\text { Sewage } \\
\text { sludge ash (S) } \\
\text { and lime (L) }\end{array}$ & $\begin{array}{l}8 \% \text { admixture } \\
\quad(\mathrm{S}: \mathrm{L} 4: 1)\end{array}$ & $\mathrm{CBR} \uparrow, \mathrm{UCS} \uparrow, \mathrm{PI} \downarrow$ \\
\hline $\begin{array}{l}\text { Sudan, } \\
\text { Khartoum [123] }\end{array}$ & 2.64 & 76 & 24 & 52 & 1.3 & $\mathrm{CH}$ & 1.49 & 26.0 & Fly ash (F) & $\begin{array}{c}10 \% \mathrm{~F}\left(\mathrm{~F}: \mathrm{SiO}_{2} \text { is }\right. \\
54 \% \text {, alumina } \\
34 \%, \mathrm{CaO} \text { is } \\
3.6 \%)\end{array}$ & $\begin{array}{l}P_{\mathrm{s}} \downarrow(50 \% \text { to } 70 \%), \\
\text { at } 25 \% \mathrm{~F}, P_{\mathrm{s}} \downarrow(90 \%), \\
\mathrm{UCS} \uparrow(\text { almost } 100 \%)\end{array}$ \\
\hline $\begin{array}{l}\text { Brazil, curitiba } \\
\text { city [143] }\end{array}$ & 2.71 & 53 & 32 & 21 & $<1$ & $\mathrm{MH}$ & 13.8 & 28.5 & Lime (L) & $9 \% \mathrm{~L}$ & $\begin{array}{c}\text { UCS (by 75\%) } \\
\text { Porosity } \downarrow, \text { MDD } \uparrow\end{array}$ \\
\hline $\begin{array}{l}\text { Spain, Granada } \\
\text { [21] }\end{array}$ & & 69 & 48 & 21 & 1.4 & $\mathrm{CH}$ & 15.7 & 40 & $\begin{array}{l}\text { Lime }(\mathrm{L}), \\
\text { steel slag }(\mathrm{S})\end{array}$ & $\begin{array}{c}\text { Dolomite L } \\
\text { (effective as } \\
\text { commercial L) S: } \\
\text { also good }\end{array}$ & $\begin{array}{c}\text { Increase in } \mathrm{pH} \uparrow \\
\text { Increase in } \mathrm{CO}_{3} \uparrow \\
\mathrm{UCS} \uparrow \text {, plasticity } \downarrow\end{array}$ \\
\hline
\end{tabular}


SEM micrographs

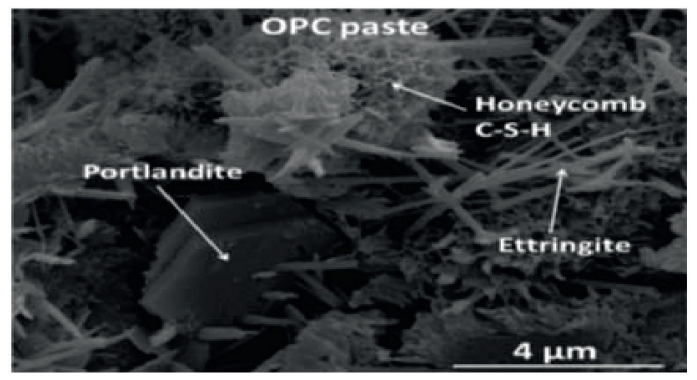

(a)

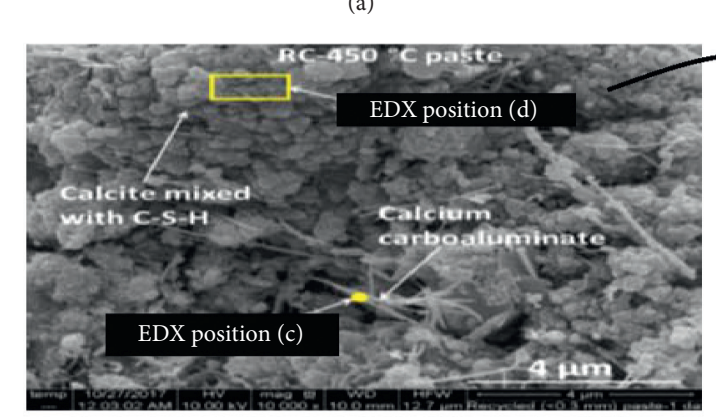

(b)

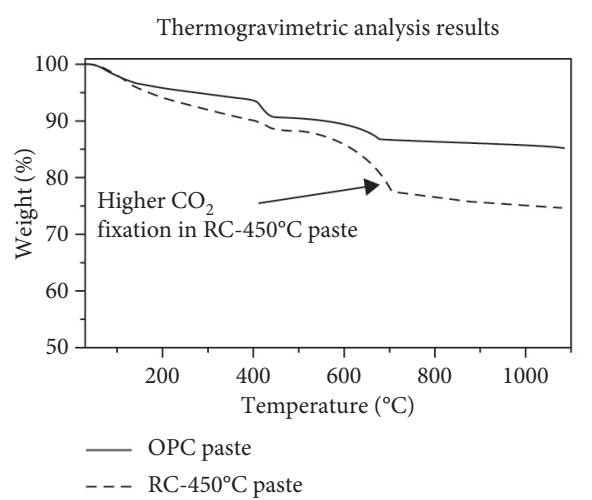

(e)

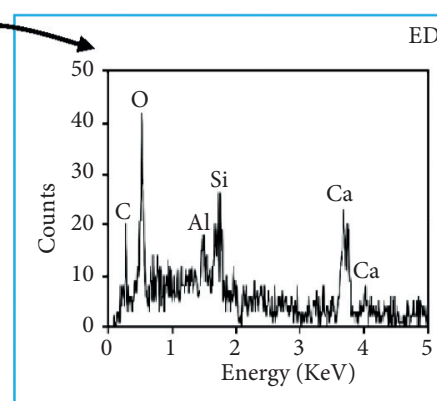

(c)

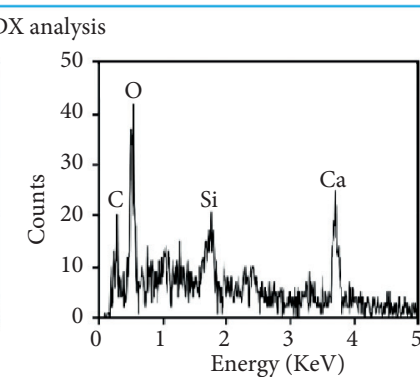

(d)

FIGURE 9: Comparison of SEM micrographs and TGA along with EDX analysis on specified locations for OPC and recycled cement (RC) $450^{\circ} \mathrm{C}$ (modified after [129]).

cement at an elevated temperature on the microstructure of expansive clay soil. So, cement proves to be more efficacious in controlling swell potential, and it is obvious that the mechanism of cement and lime stabilization of soils follows a similar pattern and yields identical results.

\subsection{Main Effect of Fly Ash and Interaction with Lime and} Cement. Fly ash (FA) controls the swell potential in expansive soils [24, 137] and is classified into several types based on the source of extraction and nature of pozzolanic behavior. The ASTM categorizes the noncrystalline FA into Class N, Class F, and Class C [71], represented here as NFA, FFA, and CFA, respectively. One advantage inherent to FA is its pozzolanic nature. CFA is obtained when subbituminous coal is burnt in plants, while generating electricity [129]. This form of CFA is being considered as an additive with highcalcium fly ash (HCFA) in conjunction with other catalytic binders and a waste material rich in silica-alumina to develop a new cold mixture for asphalt binders and emulsion mixtures in pavement design and practice [147]. In India alone, as of 2005, according to Dahale [97] the total production of FA reached $75 \mathrm{M}$ tons/year, $92 \%$ of which would go useless in contrast with findings of $\mathrm{He}$ et al. [129] for the western countries, stating the effective utilization of $70 \%$ of total FA produced. In the Table 3, Kate reported the FA with $\mathrm{CaO}$ approximately equals to $49 \%$ [96]. It can be observed from the table that all FA types have silica + alumina + iron oxide content exceeding $80 \%$ and is therefore defined as "pozzolan", according to ASTM [148].
Fly ash is a geopolymer, i.e., a cementitious additive capable of reacting with $\mathrm{H}_{2} \mathrm{O}$ in the presence of alkaline activators [96]. Activation of FA prior to stabilization using different activators (such as $\mathrm{NaOH}, \mathrm{Na}_{2} \mathrm{SO}_{4}$, and $\mathrm{K}_{2} \mathrm{SO}_{4}$ ) is necessary for their performance. In order to elevate the $\mathrm{pH}$ environment, generally $1 \% \mathrm{CaO}$ is incorporated in the industrial wastes for initiating the chemical reaction. The cementitious nature lacks because the $\mathrm{CaO}$ content in $\mathrm{FA}$ is less than $10 \%$ although the $\mathrm{Al}_{2} \mathrm{O}_{3}$ and $\mathrm{SiO}_{2}$ contents are generally high. Therefore, lime, cement, or GGBS are incorporated to enhance the pozzolanic behavior of FA [149].

Of all ASTM types of FA, the CFA proves to significantly improve the expansivity. This results in decreasing permeability, PI, FS, and $P_{\text {s }}$ of soft clays $[12,95,150]$. The cementation in expansive clays stabilized with lime, lime-FA, and OPC is associated with formation, setting, and intergrowth of gelatinous reaction products (such as crystalline, hydrous calcium silicates, and aluminates). Figure 10 highlights the particulate characteristics of four types of pozzolan. The environmental scanning electron microscopy (ESEM) is an advanced form of SEM [151]. It is shown in Figure 10 that trass pozzolan (T) has the capability to absorb large amount of water in contrast to tuff pozzolan (A) exhibiting roundish and rough surface which witnesses a lower water uptake, owing to their mineral shape, size, and orientation. The subsequent increase in angularities of pozzolan K (sharp edged, split-like grains, more even, and dense structural surface) and P (sharp-edged, split-like grains, glassy-like, and even more even and dense surface) 


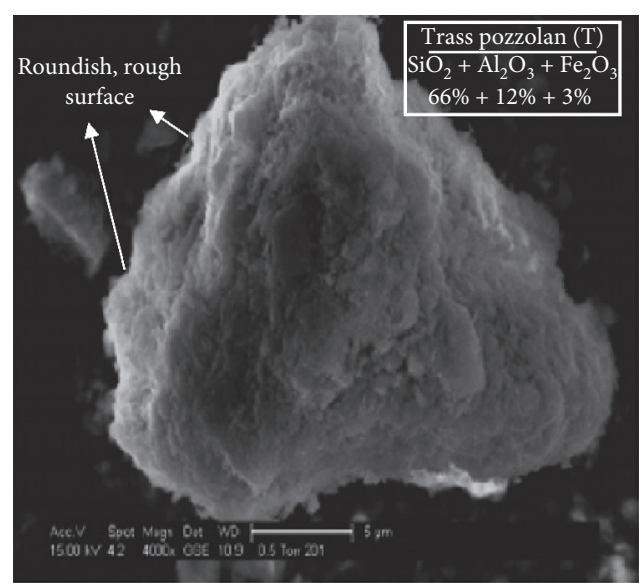

(a)

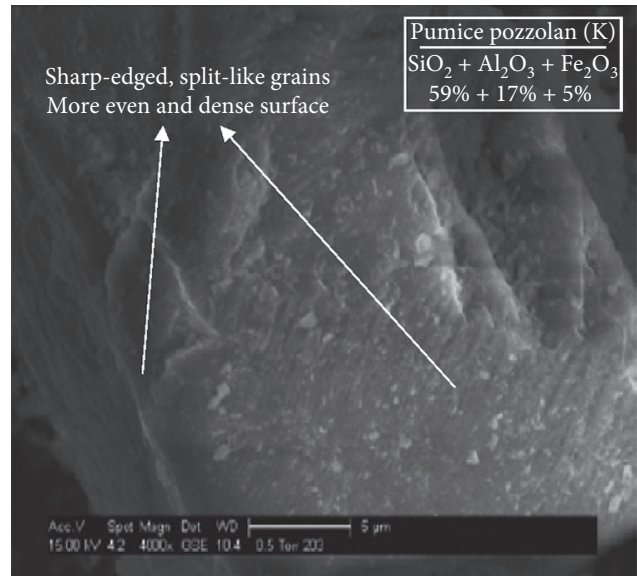

(c)

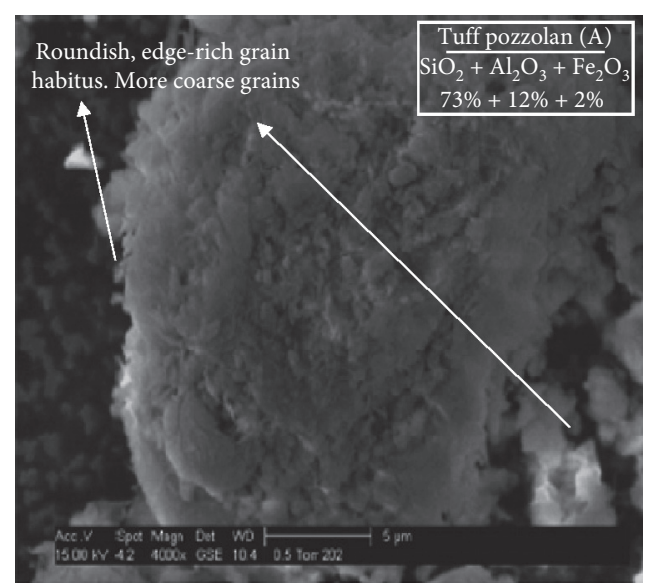

(b)

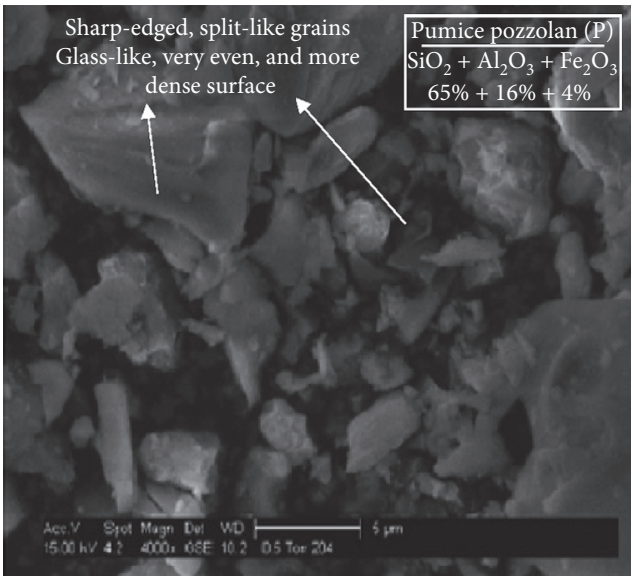

(d)

FIGURE 10: Environmental scanning electron microscope (ESEM) images of various types of pozzolans providing an insight to particulate characteristics (reproduced from research study by [121] with some modifications).

(Figures $10(\mathrm{c})$ and $10(\mathrm{~d})$, respectively) also leads to reduced water penetration [121].

In addition, the indirect tensile strength of specimen stabilized with FA can be calculated, which is helpful for soils subjected to traffic load, differential temperature, and/or nonuniform settlement, and an equation is employed on the basis of which a correlation (25\% FA treatment) has been developed to determine the Brazilian tensile strength (BTS), using the unconfined compression strength (UCS) value, in equation (8) [152]. For a given value of LL, the PI can be directly evaluated using correlation suggested in equation (9) and can further be used to determine BTS from the derived equation (10), after original equations by past researchers:

$$
\begin{aligned}
\mathrm{BTS} & =0.026 \times \mathrm{UCS}^{1.116}, \\
\mathrm{PI} & =0.11 \times \mathrm{LL}^{2}, \\
\mathrm{BTS} & =0.0012 \times \mathrm{PI}^{0.558} .
\end{aligned}
$$

The main and interaction effects of FA are briefly discussed. According to Kommu et al. [153], the FA aids in increasing OMC whereas accounts for a reduction in MDD in the presence of sand, which acts as the filler material to improve compaction characteristics due to capillary bridge. Also, by keeping FA content constant and increasing the amount of sand, the results were inversed. In terms of strength characteristics evaluation, a highest UCS value is attained with an addition of $10 \% \mathrm{FA}$ and $8 \%$ sand in the expansive soil sample, which is attributed to C-S-H gel and AFt phase formation because of FA hydration and thus significantly improving cohesion between clayey particles.

The CFA has been used in conjunction with cement and waste gypsum [97], and the maximum UCS is achieved at 28 days $(0.36 \mathrm{MPa}$ to $3.49 \mathrm{MPa}$ ) with strength reporting to be decreased by $36 \%$ at 56 days. While dealing with coal ash, the probable chromium (Cr) and lead [97] concentration is to be kept in limits [154]. According to Kolias et al. [99], the FA increases the tobermorite formation which enhances the strength, while further addition of cement provides improved setting and hardening. The mixture of cement-FA yields high early and final strength for treated soils. The FA less than $50 \%$ is optimum and. achieves the highest UCS and shear strength values. However, the strength drops beyond this threshold. 
TABle 6: Comparison of lime-activated GGBS (LAS) and lime-activated Portland cement (LPC), in perspective of stabilization.

\begin{tabular}{lcccc}
\hline LAS LPC-treated clay & $\begin{array}{c}\text { Soaked in } \mathrm{Na}_{2} \mathrm{SO}_{4} \text { for } 120 \text { days } \\
\text { (durability check) }\end{array}$ & $\begin{array}{c}\text { C-S-H formation } \\
\text { (before soaking) }\end{array}$ & $\begin{array}{c}\text { C-S-H formation } \\
\text { (after soaking) }\end{array}$ & $\begin{array}{c}\text { Compressive strength } \\
\text { (start till soaking) }\end{array}$ \\
\hline LAS-treated clays & No cracks, more durable & More & Less & Steady drop (775 kPa to 625 $\mathrm{kPa}$ ) \\
LPC-treated clays & Extensive cracks, less durable & Less & More & Sharp loss in strength gain (after 28 days) \\
\hline
\end{tabular}

LAS: lightweight alkali-activated GGBS; LPC: lightweight Portland cement.

5.4. Main Effect of GGBS and Interaction Effect with Lime and Cement. The ground granulated blast furnace slag (GGBS) is a prominent industrial waste that helps in giving long-term strength to problematic soils $[155,156]$, and sometimes, it is also used as a replacement of cement due to its high cementitious nature. Unlike lime, the GGBS is far more efficacious to stabilize the sulfate bearing soils. Much has been learnt about the physical, mechanical, and hydraulic behavior of clayey soils stabilized using GGBS and their activation with lightweight alkalis (lightweight alkali-activated GGBS (LAS)). As shown in Table 6, use of this particular CSM experiences no cracks visible to naked eye when dipped in sodium sulfate solution for four months, thereby yielding a higher compressive strength $[157,158]$. It can also be observed that C-S-H formation before soaking in case of LAS-treated clays is in more quantity than that of LPCtreated clays, and after soaking, it is vice versa. The LAStreated clays are more durable and experience fewer number of cracks when dipped in sodium sulfate solution for 120 days, in contrast with LPC-treated clays which are less durable and witness more cracks.

The role of GGBS, alone and in combination with FA and lime, in affecting the engineering characteristics is of vital importance to soil engineers, practitioners, and scientists. According to Sivapullaiah [159], the slags with a larger amount of $\mathrm{Ca}^{2+}$ ions (such as in the case of GGBS) than $\mathrm{Na}^{2+}$ ions, such as $\mathrm{Cu}$ slags, tend to minimize swell potential more effectively. It suggests that suitability of stabilizer is highly dependent on its chemical composition. In addition, Sharma and Sivapullaiah [95] and Jiang et al. [160] employed GGBS for investigating effects on expansive soils to control the uncontrollable swelling, mainly occurring in sulfate-rich soils upon $\mathrm{CaO}$ or cement addition, concluding that GGBS is a suitable material for pavement stabilization, owing to its high wear resistance. The use of GGBS in combination with lime and RHA (20\%, 5\%, and $10 \%$, respectively) is effective, as plasticity reduces drastically by $67 \%$ and the strength increase by $95 \%$ in contrast to that of virgin soil [98]. Moreover, considering the wide variation in properties of GGBS and FA, for instance, the deficiency of $\mathrm{CaO}$ in FA and the excess of $\mathrm{CaO}$ in GGBS make their "interaction effect" as superadvantageous, in terms of treating expansive soil. With using almost $10 \%$ steel slag, the MDD is expected to rise and the UCS also increases by $50 \%$. However, beyond this amount, the strength loss is reported at a much slower rate. Also, the reduction of $70 \%$ in PI is recorded at $30 \%$ steel slag content. Moreover, by using 20\% optimum blend of GGBS and FA for stabilization of high plastic clays along with $1 \%$ lime, the test results indicate reduction in LL and PI, whereas shrinkage limit, MDD, UCS, and amount of C-S-H gel produced are significantly increased. Despite high cement prices and/or unavailability of lime in some places, the GGBS-FA mix binder is cost-effective and significantly reduces the burden on environment [161].

5.5. Main Effect of Bagasse Ash and Interaction Effect with Lime and Cement. The bagasse ash is a waste in the form of agricultural byproducts which is obtained from sugarcane industry. The juice extracted from sugarcane forms a mass resembling fiber called "bagasse." When bagasse is burnt, an ash is produced in the form of fine residue, with coarsegrained structure and lower $G_{\mathrm{s}}$ value than that of soil, termed as "bagasse ash [95]." The BA is a serious issue and is usually dumped without any economic value. Being rich in $\mathrm{SiO}_{2}$ content, it is used as a pozzolanic material because the amount of alumina, silica, and calcium oxide exceeds $70 \%$. ASTM defines such materials as Class $\mathrm{N}$ or Class F pozzolan, while if the accumulated percentage exceeds $50 \%$, then it is categorized as Class C pozzolan [149]. In addition, it has been confirmed from leaching tests on expansive soil stabilized with bagasse ash that it is suitable for stabilization of road subgrades owing to its nonhazardous nature [162, 163]. The addition of BA reduces the PI, swell, alkalinity of soil matrix, and cation exchange value while increases the $\mathrm{CaCO}_{3}$ content and the total soluble solids [3].

The improvement mechanism of $\mathrm{BA}$ is identical to the chemical reaction involved in cement stabilization. The clay reacts with lime and BA resulting in flocculation and the cation exchange phenomenon that is a "short-term reaction." Then, the formation of C-S-H and C-A-H gels takes place, due to the pozzolanic reaction, giving "long-term strength" to the soils $[164,165]$. However, the strength gain and durability are quite low when BA is used alone for purpose of stabilization. However, it effectively lowers the PI, FS, and $P_{\mathrm{s}}$ values [68]. The UCS of high expansive soil, when treated with $0.5 \% \mathrm{BA}+6.25 \%$ lime mix and cured for three days, witnessed a dramatic increase of almost $96 \%$ as compared to when no lime treatment was done. Similarly, for the same dosage levels of stabilizer contents cured for 28 days, the percentage increase in strength was about $150 \%$, reflecting the effectiveness of curing in the strength gain process [166]. The MDD drops, and the OMC rises when ( $8 \% \mathrm{BA}+16 \%$ lime sludge) mix is incorporated in expansive soil $\left(\mathrm{LL}=60 \%, \mathrm{PI}=28 \%, P_{\mathrm{s}}=128 \mathrm{kN} / \mathrm{m}^{2}\right)$ [167]. In Figure 11 , the increase in RHA from 0 to $7.5 \%$ indicates a gradual increase in the UCS and later drops when further increased up to $12.5 \%$. The trend of CDA is almost similar to that of SCBA. In contrast, following the same pattern, RHA experiences a sharp rate of strength gain and strength loss. Therefore, it can be concluded that BA is a less effective stabilizer and its performance is highly improved when lime 

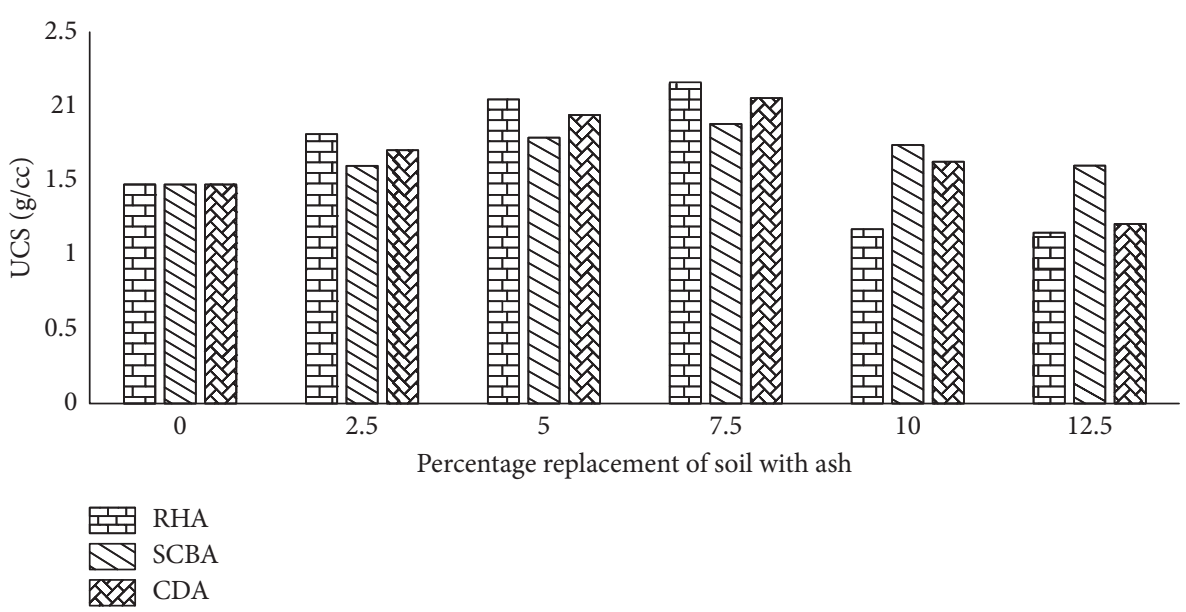

FIGURE 11: Stabilization of subgrade soil in India using indigenous nonplastic materials such as rice husk ash (RHA), sugarcane bagasse ash (SCBA), and cow dung ash (CDA). The in situ soil (depth of $1.5 \mathrm{~m}-2.5 \mathrm{~m}$ was intermediate plastic clay (figure taken from [168]).

is added to it, and the curing period is increased up to 28 days.

\subsection{Efficacy of Other Eco-Friendly Stabilizer Materials.} The extent of other CSMs cannot comprehensively be enclosed in one research paper; however, few eminent materials are presented in this section, for instance, calcium carbon residue (CCR), groundnut shell ash (GSA), and sewage sludge ash (SSA).

When acetylene is burnt, calcium carbon residue (CCR) is produced. It is deleterious in nature but rich in lime [138] content; therefore, it can be used to modify the properties of expansive soils [169]. The stabilization with CCR achieves better results than with lime from the viewpoint of economy and environment [170]. Horpibulsuk categorized the strength development of CCR-stabilized soils into three zones, namely, active, inert, and deterioration zones. Only the first two zones are beneficial with respect to strength improvement. In the first zone (i.e., CCR less than 7\%), the natural pozzolanic material is sufficient for the pozzolanic reaction. Hence, the FA is not required to further improve the strength. But, in the inert zone (i.e., CCR between $7 \%$ and $11 \%$ ), the strength gain is achieved by adding FA which helps in densification and speeding up the pozzolanic reaction [78]. Moreover, Somna et al. [171] utilized CCR-RHA mix and recorded $22 \%$ increase in the UCS upon curing from 28 days to 180 days. These materials are also employed for yielding high strength concrete in construction. In addition, BA and CCR are mixed in combination for making the stabilized mix more ductile. In the stabilization of soft Bangkok clay, the pozzolanic reaction intensified as the amorphous Si from BA was dissolved in alkaline environment and reacted with the CCR [172]. With 8\% CCR treatment, for no BA content and with $9 \%$ BA after 36 days curing, the change in UCS was as high as $400 \%$ [173].

Ground nuts are grown in abundance in different regions of the world approximately 20,000,000 hectares per annum [174]. The use of GSA, a form of agricultural waste, is useful in waste management. It needs to be safely disposed to avoid polluting the environment [93]. Addition of GSA to black cotton soil ( $\mathrm{LL}=83.36 \%$ and $\mathrm{PI}=89.32 \%$ ) significantly improved the compaction and strength characteristics. However, it cannot be used as standalone stabilizer for road construction owing to the smaller value of CBR after stabilization [175]. Venkatraman et al. [176] concluded from his study on the settlement behavior of clayey soil using the plate load test that the GSA stabilization enhances the ultimate bearing capacity. GSA and cement increased the optimum moisture content [177] whereas slightly decreased the dry density as well as the modulus of elasticity of soil. The ( $2 \%$ GSA $+0.1 \%$ cement) blend may be used as a feasible alternative in pavement construction and for stabilizing soil where load is emplaced [103]. The GSA with dosage levels increased from $4 \%$ to $6 \%$ was applied to low plasticity clay and a rise of $15 \%$ in UCS at 7 days was recorded, which fell short of standard requirement for stabilization of base materials [178]. Behnood [12] enumerated that $8 \%$ GSA is helpful in mitigating the swell by effectively lowering down the PI value.

SSA resembles $\mathrm{FA}$ in terms of cementitious nature has a higher percentage of $\mathrm{Ca}^{2+}$ in SSA (8\%) than in FA (3 to 5\%) [162] and acts as an efficient stabilizer. Sewage sludge blended with coal fly ash (CFA) can lower the availability of heavy metals such as $\mathrm{Cu}, \mathrm{Zn}$, and $\mathrm{Cd}$ in the sludge [179]. Behnood [12] outlined that SSA effectively modifies the properties of CL soil by increasing their UCS, CBR, cohesion, and shear strength while reducing the swelling and angle of internal friction [180]. The UCS of specimens was improved 3-7 times by using incinerated sewage sludge ash (ISSA) and cement. Also, the swelling behavior was reduced by $10-60 \%$, and the improvement in the CBR values was up to 30 times [181]. 8\% SSA + lime can change untreated expansive from weak subgrade soil to better subgrade soil in road construction [137].

\section{Discussion}

It has been evolved to this day that the evaluation of stabilization of expansive soils is well documented in a 
series of diverse philosophies laid down, wherein a variety of CSM have been employed for stabilizing low to high range expansive soils. However, one significant shortcoming associated with the use of CSM is the increased brittleness; therefore, several stabilized elements are incorporated to overcome this problem [173]. The two prominent and conventional CSMs, lime and cement, witness brittle failure in the modified soil matrix system. Lime stabilization is commonly and widely used for road pavements. According to findings of Bell [117] and Mukhtar et al. [118], the optimum percentage of lime (for $\mathrm{pH}=12.4$ ) ranges between $4 \%$ and $8 \%$, depending upon the soil conditions and type of soil. However, if used in excess that is 6\% and more, Tran et al. [119] emphasized that lime treatment may undergo significant reduction in compressive and shear strength (of up to $30 \%$, or even more) because of requirement of large amount of water and higher initial porosity. As a result, the unconsumed hydrated lime becomes unreactive in the strength gain process [120]. Cement provides the highest strength among other CSMs, whereas lime containing excess of free lime is suitable for materials with PI $>10 \%$ as the free lime reacts with clay particles to reduce the plasticity. Lime cement blends are usually limited to stabilize materials with PI $<10 \%$. The strength achieved depends on amount of stabilizing agent incorporated and the type of material treated. However, excessive cement may be detrimental for the subgrade performance as it could form semibrittle materials [13].

The results of XRD and XRF of lime-treated soils revealed the significant mineralogical changes upon treatment. The long-term strength is improved when curing is done, and the strength increase upon treatment of $4 \%$ lime in low swelling clays (i.e., kaolinite) is the highest in comparison to the lowest strength for the case of high swelling clay minerals (e.g., Mt). This is associated with the replacement of calcium hydroxide with calcium oxide at the early stages of lime mixing with the soil. According to Behnood [12], soil stabilization with lime in the regions exposed to severe weathering is less effective (at low lime content) because the beneficial effect of lime stabilization in reducing the swell potential of lime-treated soil is reduced in this condition. However, for many other scenarios, lime stabilization of expansive soils is still regarded as an effective approach to minimize the swelling potential. According to Dafalla et al. [104], when laminated clay is stabilized using lime, the PI value reduces more effectively for soils containing calcic Mt or sodic Mt than clays with kaolinite. However, Al-Rawas [71] argue that lime modification may be unsuitable for soils with content of Mt in excess of $40 \%$, which is having $8 \%$ as the optimum lime dosage level. It is explained by the notion that, with increase in Mt percentage in the clay fraction, a simultaneous increase in volumetric strain is also accompanied, depicting the effect of mineralogical properties of expansive clay on long-term characteristics of chemical stabilizer materials. The microstructural characteristics indicate that $\mathrm{PI}$ is significantly increased with $8 \%$ lime due to [50] formation of C-S-H and C-A-H gels [117], which fill the pores in clays with discontinuous structure [122] and (2) increase in calcium to silica ratio. According to Dash and Hussain [115], these studies are in good agreement with those observed for microstructural behavior of expansive soils. Thus, lime stabilization is feasible for $\mathrm{SiO}_{2}$-rich soils, soils having gypsum, and the soils containing iron with varying optimum percentage of lime for each, depending on presence of respective ingredient. However, in $\mathrm{SO}_{4}$-rich soils, the use of lime is not recommended since there is no hydrated calcium oxide available. Because when in absence of sulfates, the CEC of the soil greatly depends on its negatively charged particles [182]. Thus, it can be inferred that lime stabilization of expansive soils is mainly function of environment of lime-soil reactions and type of clay minerals.

For cement versus lime stabilization, it is often misinterpreted that both stabilizers are identical in yielding results in terms of C-S-H and C-A-H formation, but cement proves to be a relatively better choice. Few common characteristics related to the cement stabilization are briefly discussed. Cement assists in minimizing the toxicity level from certain wastes, for instance, agricultural or industrial waste, and causes reduction in PI and swell potential. Generally, $10 \%$ cement is considered as optimum for treating medium to high expansive soils, whereas the variation in improvement widely varies when it is used between $2-10 \%$ because of varying soil type, weathering effects, and period of curing. Cement is not used for soils with PI higher than $30 \%$. Therefore, lime is usually added to the soil prior to cement mixing for workability. Cement reduces swell more effectively than lime does. It can be inferred that (i) the rate of decrease for both FS and $P_{\mathrm{s}}$ with the addition of $2 \%$ cement is significant. An increase up to $12 \%$ cement causes uniform and gradual reduction in $P_{\mathrm{s}}$ and a relatively nonuniform but a gradual decrease in FS. Also, the modification mechanism of cement and lime is more or less similar because $\mathrm{C}-\mathrm{S}-\mathrm{H}$ and $\mathrm{C}-\mathrm{A}-\mathrm{H}$ gels formation leads to cementitious links with the untreated expansive soil particles particularly containing organic matter. [183] A general increasing trend is observed in UCS values with higher CKD content along with the curing time for problematic soil (with a potential for a time-dependent increase in strength). So, strength increases with more curing. Therefore, further studies on longer curing times and possibly increased CKD contents are required. CKD, volcanic ash, and their mixes are helpful in reducing cost of construction of small-scale houses and pavements, in terms of strength and durability aspects [171]. It is important to mention here that blend of $5 \%$ lime and $3 \%$ cement will effectively reduce the PI by $60 \%$ and $P_{s}$ by $82 \%$. Thus, cement is more efficacious in controlling swell potential although the mechanism behind stabilizing soils by cement and lime follows a similar pattern and results in general.

Fly ash less than $50 \%$ is suffice for increasing the OMC and reducing the MDD in expansive soils, thereby achieving higher UCS and shear strength values. But a successful treatment requires an alkali activator due to the inherent lack of calcium oxide (less than 10\%) in FA. It is said that $1 \%$ lime is suited for compensation, but the rate of increase of OMC and MDD is still important. While modifying the 
capacity against expansion, FA is also proven to increase the strength of expansive soils, such as adding $10 \%$. But an optimized dosage for a joint application, for example, both increasing UCS while reducing expansion is still open for further investigation leading to introduction of multipurpose FAs. To this end, modified FAs, such as CFA, FA-sandmarble dust, and variety of similar materials are incorporated to reduce the PI, FS, and $P_{\mathrm{s}}$ of soils as feasible mixtures in practice as, for example, in flexible pavement where both strength and expansion are significant.

The ground-granulated blast furnace slag is another highly cementitious one, and it also needs an activator, generally with lightweight alkali. GGBS lacks binder leading to a more $\mathrm{CaO}$ presence compared with lime which due to less cementitious nature has less $\mathrm{CaO}$ content. As a result, both GGBS and lime are used in conjunction, and it is established that 20\% GGBS and 1\% lime will effectively reduce LL and PI and increase the MDD, UCS, and C-S-H formation. The ground basic oxygen furnace slag (GBOFS) performs better than the GGBS. In a study by Goodarzi and Salimi [109], 10\% GBOFS is sufficient to eliminate dispersion in soil, whereas a greater percentage of GGBS (i.e., $20-25 \%)$ is required for achieving the same impact. It is attributed to the lower activity (crystalline nature) of GGBS in contrast to that of GBOFS. One associated shortcoming is that the ultimate improvement in engineering properties requires still a higher percentage (15-20\%) of GBOFS along with increased curing time [12].

Owing to its nonhazardous nature and suitability for road subgrades, bagasse ash alone used for stabilizing soil affects the durability. The improvement mechanism of BA resembles with that of cement stabilization. For better results, lime should be added to the BA. It is observed that $0.6 \%$ BA and $6.25 \%$ lime will increase the strength by $96 \%$ after curing for three days, suggesting that curing plays a major role. Indicating the fact that BA is a less effective stabilizer, its performance is highly improved when lime is added to it with increased curing.

\section{Conclusions and Recommendations}

This study reviews the trends in stabilization of low to high expansive soils with Ca-based materials (CSMs). The influence of the effectively proven CSMs on the engineering, geotechnical, and microstructural properties of expansive soils used in soil stabilization has been evaluated. In addition, the recent studies stressing the use of more environmentally friendly and nonconventional stabilization materials and techniques have also been discussed. In the light of discussions in this study, the main conclusions and findings are stated as follows:

(1) The microstructure of expansive soil is a key parameter in evaluating the swell-shrink properties, compressive strength behavior, and the environmental potential in various soil stabilization projects. A successful and reliable choice of stabilizers should be on the basis of their subsequent effect on the microstructure.
(2) Along with the microstructure effects, the rate of hydration and pozzolanic reactions in the polymerization process and cementation play a major role in the required duration and condition of soil curing. Before soil stabilization with the selected CSM, an optimum dosage and methodology of practical application on the host soil should be characterized.

(3) In accordance with the past literature, Table 5 is created with the knowledge of the variety of expansive soils across the globe using different CSMs in order to quantify the main and interaction effects of the type of stabilizers in terms of the applicable host soil, optimum CSM dosage incorporated, and the associated improved properties.

(4) Despite cement being the widely used CSM, considering the expenses and challenge of $\mathrm{CO}_{2}$ emission and associated toxicity levels in treated soils, lime alongside other pozzolans (FA, BA, GGBS, CCR, GSA, and SSA in order of their practical efficiency) is more beneficial option for stabilizing expansive soils.

In addition, this study identifies research needs for future including energy perspectives with respect to sustainable local construction and developing a satisfactory protocol explaining the stabilization mechanisms. The search for choosing environmentally friendly biomaterials and numerous waste materials is still under investigation and is needed to maintain global sustainability standards.

\section{Conflicts of Interest}

The authors declare that they have no conflicts of interest.

\section{Acknowledgments}

The key project of the National Natural Science Foundation of China (Grant no. 41630633) is acknowledged for the financial support. The authors would like thank Professor Shui Long Shen for his motivation in writing this manuscript and Engr. Aminul Haque and Engr. Farjad Iqbal for their valuable comments in finalizing this review article. The authors also wish to thank the esteemed referees for providing insightful suggestions to improve this manuscript.

\section{References}

[1] L. C. Dang, B. Fatahi, and H. Khabbaz, "Behaviour of expansive soils stabilized with hydrated lime and bagasse fibres," Procedia Engineering, vol. 143, pp. 658-665, 2016.

[2] H. King: Expansive Soils and Expansive Clay: The Hidden Force behind Basement and Foundation Problems, 2015, http://www.coinspection.com/uploads/1/1/2/4/11243167/ geology.com_articles_expansive-soil.pdf.

[3] C. Rajakumar and T. Meenambal, "Experimental study of bagasse ash utilisation for road application on expansive soil," Nature Environment \& Pollution Technology, vol. 14, no. 4, 2015. 
[4] S. A. Aiban, "Compressibility and swelling characteristics of Al-Khobar Palygorskite, eastern Saudi Arabia," Engineering Geology, vol. 87, no. 3-4, pp. 205-219, 2006.

[5] B. Zhang, W. Shen, J. Wang, W. Zhang, W. Zhu, and Y. Liu, "Slight-expansive road base course binder: properties, hydration and performance," Construction and Building Materials, vol. 150, pp. 626-633, 2017.

[6] G. M. S. Abdullah and H. I. Al-Abdul Wahhab, "Evaluation of foamed sulfur asphalt stabilized soils for road applications," Construction and Building Materials, vol. 88, pp. 149-158, 2015.

[7] P. K. Gautam, P. Kalla, A. S. Jethoo, R. Agrawal, and H. Singh, "Sustainable use of waste in flexible pavement: a review," Construction and Building Materials, vol. 180, pp. 239-253, 2018.

[8] H. Jiang, B. Wang, H. I. Inyang, J. Liu, K. Gu, and B. Shi, "Role of expansive soil and topography on slope failure and its countermeasures, Yun County, China," Engineering Geology, vol. 152, no. 1, pp. 155-161, 2013.

[9] M. Gougazeh and A. Al-Shabatat, "Geological and geotechnical properties of soil materials at Tannur dam, Wadi Al Hasa, South Jordan," Journal of Taibah University for Science, vol. 7, no. 4, pp. 216-224, 2013.

[10] T. M. Petry and D. N. Little, "Review of stabilization of clays and expansive soils in pavements and lightly loaded structures-history, practice, and future," Journal of Materials in Civil Engineering, vol. 14, no. 6, pp. 447-460, 2002.

[11] K. B. Simons, "Limitations of residential structures on expansive soils," Journal of Performance of Constructed Facilities, vol. 5, no. 4, pp. 258-270, 1991.

[12] A. Behnood, "Soil and clay stabilization with calcium- and non-calcium-based additives: a state-of-the-art review of challenges, approaches and techniques," Transportation Geotechnics, vol. 17, pp. 14-32, 2018.

[13] C. Godenzoni: Multiscale Rheological and Mechanical Characterization of Cold Mixtures, 2017, https://scholar. google.com/scholar?hl=en\&as_sdt $=0 \% 2 \mathrm{C} 5 \& \mathrm{q}=$ Multiscale+ Rheological+and+Mechanical+Characterization+of+Cold+ Mixtures\&btnG $=$.

[14] K. Yan and L. Wu, "Swelling behavior of compacted expansive soils, recent advancement in soil behavior," in Proceedings of the Situ Test Methods, Pile Foundations, and Tunneling: Selected Papers from the 2009 GeoHunan International Conference, pp. 1-6, Changsha, China, August 2009.

[15] C. C. Ikeagwuani and D. C. Nwonu, "Emerging trends in expansive soil stabilisation: a review," Journal of Rock Mechanics and Geotechnical Engineering, vol. 11, no. 2, pp. 423-440, 2019.

[16] I. Yilmaz and B. Civelekoglu, "Gypsum: an additive for stabilization of swelling clay soils," Applied Clay Science, vol. 44, no. 1-2, pp. 166-172, 2009.

[17] C. Kurtulus, F. Sertcelik, M. M. Canbay, and İ. Sertcelik, "Estimation of Atterberg limits and bulk mass density of an expansive soil from P-wave velocity measurements," Bulletin of Engineering Geology and the Environment, vol. 69, no. 1, pp. 153-154, 2010.

[18] P. Priyadharshini, K. Ramamurthy, and R. G. Robinson, "Reuse potential of stabilized excavation soil as fine aggregate in cement mortar," Construction and Building Materials, vol. 192, pp. 141-152, 2018.

[19] M. L. Nehdi, "Clay in cement-based materials: critical overview of state-of-the-art," Construction and Building Materials, vol. 51, pp. 372-382, 2014.
[20] E. Celik and Z. Nalbantoglu, "Effects of ground granulated blastfurnace slag (GGBS) on the swelling properties of limestabilized sulfate-bearing soils," Engineering Geology, vol. 163, pp. 20-25, 2013.

[21] M. Sol-Sánchez, J. Castro, C. G. Ureña, and J. M. Azañón, "Stabilisation of clayey and marly soils using industrial wastes: $\mathrm{pH}$ and laser granulometry indicators," Engineering Geology, vol. 200, pp. 10-17, 2016.

[22] M. F. Iqbal, Q.-F. Liu, I. Azim et al., "Prediction of mechanical properties of green concrete incorporating waste foundry sand based on gene expression programming," Journal of Hazardous Materials, vol. 384, p. 121322, 2020.

[23] J. K. Mitchell and K. Soga, "Fundamentals of soil behavior," Fundamentals of Soil Behavior, Vol. 3, John Wiley \& Sons, New York, NY, USA, 2005.

[24] J. Nelson and D. J. Miller, Expansive Soils: Problems and Practice in Foundation and Pavement Engineering, John Wiley \& Sons, Hoboken, NJ, USA, 1997.

[25] D. Mašín and N. Khalili, "Swelling phenomena and effective stress in compacted expansive clays," Canadian Geotechnical Journal, vol. 53, no. 1, pp. 134-147, 2015.

[26] $\mathrm{Y} . \mathrm{Xu}$, "Fractal model for the correlation relating total suction to water content of bentonites," Fractals, vol. 26, no. 3, Article ID 1850028, 2018.

[27] V. Ouhadi and R. Yong, "The role of clay fractions of marly soils on their post stabilization failure," Engineering Geology, vol. 70, no. 3-4, pp. 365-375, 2003.

[28] R. Katti, U. Kulkarni, A. Katti, and R. Kulkarni, "Stabilization of embankment on expansive soil-a case study," in Proceedings of the Experimental and Applied Modeling of Unsaturated Soils GeoShanghai International Conference, pp. 181-189, Shanghai, China, June 2010.

[29] C. Shi, Y. Wu, C. Riefler, and H. Wang, "Characteristics and pozzolanic reactivity of glass powders," Cement and Concrete Research, vol. 35, no. 5, pp. 987-993, 2005.

[30] L. Liu, "Prediction of swelling pressures of different types of bentonite in dilute solutions," Colloids and Surfaces A: Physicochemical and Engineering Aspects, vol. 434, pp. 303318, 2013.

[31] A. M. Awad, S. M. Shaikh, R. Jalab et al., "Adsorption of organic pollutants by natural and modified clays: a comprehensive review," Separation and Purification Technology, vol. 228, Article ID 115719, 2019.

[32] Y.-J. Cui, "On the hydro-mechanical behaviour of MX80 bentonite-based materials," Journal of Rock Mechanics and Geotechnical Engineering, vol. 9, no. 3, pp. 565-574, 2017.

[33] A. A. Boateng and D. A. Skeete, "Incineration of rice hull for use as a cementitious material: the Guyana experience," Cement and Concrete Research, vol. 20, no. 5, pp. 795-802, 1990.

[34] S. Pourakbar, A. Asadi, B. B. K. Huat, and M. H. Fasihnikoutalab, "Stabilization of clayey soil using ultrafine palm oil fuel ash (POFA) and cement," Transportation Geotechnics, vol. 3, pp. 24-35, 2015.

[35] V. Cantillo, V. Mercado, and C. Pájaro, "Empirical correlations for the swelling pressure of expansive clays in the city of Barranquilla, Colombia," Earth Sciences Research Journal, vol. 21, no. 1, pp. 45-49, 2017.

[36] H. Elbadry, "Simplified reliable prediction method for determining the volume change of expansive soils based on simply physical tests," HBRC Journal, vol. 13, no. 3, pp. 353-360, 2017. 
[37] N. Huvaj and E. Uyeturk, "Effects of drying on atterberg limits of pyroclastic soils of northern Turkey," Applied Clay Science, vol. 162, pp. 46-56, 2018.

[38] A. A. Basma, A. S. Al-Homoud, and A. Husein, "Laboratory assessment of swelling pressure of expansive soils," Applied Clay Science, vol. 9, no. 5, pp. 355-368, 1995.

[39] H. Akgün, A. Günal Türkmenoğlu, A. Arslan Kelam, K. Yousefi-Bavil, G. Öner, and M. K. Koçkar, "Assessment of the effect of mineralogy on the geotechnical parameters of clayey soils: a case study for the Orta County, Çankırı, Turkey," Applied Clay Science, vol. 164, pp. 44-53, 2018.

[40] E. Mehmood, M. Ilyas, and K. Farooq, "Effect of initial placement conditions on swelling characteristics of expansive soils," in Proceedings of the Geo-Frontiers 2011: Advances in Geotechnical Engineering, pp. 2397-2403, Dallas, TX, USA, March 2011.

[41] B. Shi, H. Jiang, Z. Liu, and H. Fang, "Engineering geological characteristics of expansive soils in China," Engineering Geology, vol. 67, no. 1-2, pp. 63-71, 2002.

[42] A. A. Al-Rawas, "The factors controlling the expansive nature of the soils and rocks of northern Oman," Engineering Geology, vol. 53, no. 3-4, pp. 327-350, 1999.

[43] D. R. Katti, M. I. Matar, K. S. Katti, and P. M. Amarasinghe, "Multiscale modeling of swelling clays: a computational and experimental approach," KSCE Journal of Civil Engineering, vol. 13, no. 4, pp. 243-255, 2009.

[44] K. Prakash and A. Sridharan, "Free swell ratio and clay mineralogy of fine-grained soils," Geotechnical Testing Journal, vol. 27, no. 2, pp. 220-225, 2004.

[45] Y. Xu, "Peak shear strength of compacted GMZ bentonites in saline solution," Engineering Geology, vol. 251, pp. 93-99, 2019.

[46] ASTM, Standard Test Methods for One-Dimensional Swell or Settlement Potential of Cohesive Soils, ASTM, West Conshohocken, PA, USA, 2003.

[47] J. D. Nelson, K. C. Chao, D. D. Overton, and E. J. Nelson, Foundation Engineering for Expansive Soils, John Wiley \& Sons, Hoboken, NJ, USA, 2015.

[48] A. Aqeel, "Investigation of expansive soils in Obhor Sabkha, Jeddah-Saudi Arabia," Arabian Journal of Geosciences, vol. 9, no. 4, p. 314, 2016.

[49] B. A. Hakami and E.-S. S. A. Seif, "Expansive potentiality of Sabkha soils of Rabigh Lagoon, Saudi Arabia: a case study," Arabian Journal of Geosciences, vol. 12, no. 4, p. 107, 2019.

[50] I. M. Idriss and R. W. Boulanger, "SPT-based liquefaction triggering procedures," Report UCD/CGM-10/02, Department of Civil and Environmental Engineering, University of California, Davis, CA, USA, p. 259, 2010.

[51] M. Labib and A. Nashed, "GIS and geotechnical mapping of expansive soil in Toshka region," Ain Shams Engineering Journal, vol. 4, no. 3, pp. 423-433, 2013.

[52] A. Puppala, L. Hoyos, C. Viyanant, and C. Musenda, "Fiber and fly ash stabilization methods to treat soft expansive soils," in Proceedings of the Soft Ground Technology, pp. 136-145, Noordwijkerhout, Netherlands, May 2001.

[53] M. M. Zumrawi, "Construction problems of light structures founded on expansive soils in Sudan," International Journal of Science and Research (IJSR), vol. 4, no. 8, pp. 896-902, 2015.

[54] A. Al-Swaidani, I. Hammoud, and A. Meziab, "Effect of adding natural pozzolana on geotechnical properties of limestabilized clayey soil," Journal of Rock Mechanics and Geotechnical Engineering, vol. 8, no. 5, pp. 714-725, 2016.
[55] S. I. Cetiner, Stabilization of Expansive Soils by Çayirhan Fly Ash and Desulphogypsum, Middle East Technical University, Ankara, Turkey, 2004.

[56] D. W. Smith, G. A. Narsilio, and P. Pivonka, "Numerical particle-scale study of swelling pressure in clays," KSCE Journal of Civil Engineering, vol. 13, no. 4, pp. 273-279, 2009.

[57] Y. S. Wibowo, "Perilaku Sifat Fisik dan Keteknikan Tanah residual Batuan Volkanik Kuarter Di Daerah Cikijing, Majalengka, Jawa Barat," RISET Geologi Dan Pertambangan, vol. 21, no. 2, pp. 131-139, 2011.

[58] P. V. Muthyalu, K. Ramu, and G. P. Raju, "Study on performance of chemically stabilized expansive soil," International Journal of Advances in Engineering \& Technology, vol. 2, no. 1, p. 139, 2012.

[59] M. Malekzadeh and H. Bilsel, "Hydro-mechanical behavior of polypropylene fiber reinforced expansive soils," KSCE Journal of Civil Engineering, vol. 18, no. 7, pp. 2028-2033, 2014.

[60] F. Mousavi, E. Abdi, and H. Rahimi, "Effect of polymer stabilizer on swelling potential and CBR of forest road material," KSCE Journal of Civil Engineering, vol. 18, no. 7, pp. 2064-2071, 2014.

[61] H. Zhao, L. Ge, T. M. Petry, and Y.-Z. Sun, "Effects of chemical stabilizers on an expansive clay," KSCE Journal of Civil Engineering, vol. 18, no. 4, pp. 1009-1017, 2014.

[62] M. Dafalla and M. Shamrani, "Road damage due to expansive soils: survey of the phenomenon and measures for improvement," in Proceedings of the Design, Construction, Rehabilitation, and Maintenance of Bridges, pp. 73-80, Hunan, China, 2011.

[63] A. J. Puppala and A. Pedarla, "Innovative ground improvement techniques for expansive soils," Innovative Infrastructure Solutions, vol. 2, no. 1, p. 24, 2017.

[64] A. Al-Taie, M. M. Disfani, R. Evans, A. Arulrajah, and S. Horpibulsuk, "Swell-shrink cycles of lime stabilized expansive subgrade," Procedia Engineering, vol. 143, pp. 615622, 2016.

[65] W. D. Lawson, A Survey of Geotechnical Practice for Expansive Soils in Texas, Unsaturated Soils 2006, American Society of Civil Engineers, Reston, VA, USA, 2006.

[66] M. Iqbal, Q. Liu, and I. Azim, "Experimental study on the utilization of waste foundry sand as embankment and structural fill," in Proceedings of the IOP Conference Series: Materials Science and Engineering, Article ID 012042, Bangkok, Thailand, May 2019.

[67] M. De Beer, Aspects of the Design and Behaviour of Road Structures Incorporating Lightly Cementitious Layers, University of Pretoria, Pretoria, South Africa, 2008.

[68] H. Hasan, L. Dang, H. Khabbaz, B. Fatahi, and S. Terzaghi, "Remediation of expansive soils using agricultural waste bagasse ash,” Procedia Engineering, vol. 143, pp. 1368-1375, 2016.

[69] R. N. Yong and V. R. Ouhadi, "Experimental study on instability of bases on natural and lime/cement-stabilized clayey soils," Applied Clay Science, vol. 35, no. 3-4, pp. 238-249, 2007.

[70] H. H. Adem and S. K. Vanapalli, "Review of methods for predicting in situ volume change movement of expansive soil over time," Journal of Rock Mechanics and Geotechnical Engineering, vol. 7, no. 1, pp. 73-86, 2015.

[71] A. A. Al-Rawas, A. W. Hago, and H. Al-Sarmi, "Effect of lime, cement and Sarooj (artificial pozzolan) on the swelling potential of an expansive soil from Oman," Building and Environment, vol. 40, no. 5, pp. 681-687, 2005. 
[72] Y. Liu, Y. Su, A. Namdar et al., "Utilization of cementitious material from residual rice husk ash and lime in stabilization of expansive soil," Advances in Civil Engineering, vol. 2019, pp. 1-17, 2019.

[73] M. M. Zumrawi, "Geotechnical aspects for roads on expansive soils," International Journal of Scientific Research, vol. 4, pp. 896-902, 2015.

[74] C. Godenzoni, A. Graziani, E. Bocci, and M. Bocci, "The evolution of the mechanical behaviour of cold recycled mixtures stabilised with cement and bitumen: field and laboratory study," Road Materials and Pavement Design, vol. 19, no. 4, pp. 856-877, 2018.

[75] M. A. Rahgozar, M. Saberian, and J. Li, "Soil stabilization with non-conventional eco-friendly agricultural waste materials: an experimental study," Transportation Geotechnics, vol. 14, pp. 52-60, 2018.

[76] A. Kumar and D. Gupta, "Behavior of cement-stabilized fiber-reinforced pond ash, rice husk ash-soil mixtures," Geotextiles and Geomembranes, vol. 44, no. 3, pp. 466-474, 2016.

[77] V. Ortega-López, J. M. Manso, I. I. Cuesta, and J. J. González, "The long-term accelerated expansion of various ladle-furnace basic slags and their soil-stabilization applications," Construction and Building Materials, vol. 68, pp. 455-464, 2014.

[78] S. Horpibulsuk, C. Phetchuay, A. Chinkulkijniwat, and A. Cholaphatsorn, "Strength development in silty clay stabilized with calcium carbide residue and fly ash," Soils and Foundations, vol. 53, no. 4, pp. 477-486, 2013.

[79] Y. Shang and Y. Fu, "Experimental study of the mechanical properties of expansive soil with added nanomaterials," Arabian Journal of Geosciences, vol. 11, no. 8, p. 180, 2018.

[80] A. K. Sabat, "Statistical models for prediction of swelling pressure of a stabilized expansive soil," Electronic Journal of Geotechnical Engineering, vol. 17, pp. 837-846, 2012.

[81] A. Graziani, C. Iafelice, S. Raschia, D. Perraton, and A. Carter, "A procedure for characterizing the curing process of cold recycled bitumen emulsion mixtures," Construction and Building Materials, vol. 173, pp. 754-762, 2018.

[82] A. Graziani, C. Iafelice, S. Raschia, A. Carter, and D. Perraton, A Laboratory Approach for Characterizing the Evolutive Behavior of Cold Recycled Mixtures, 2018.

[83] E. Otte, A Structural Design Procedure for Cement-Treated Layers in Pavements, University of Pretoria, Pretoria, South Africa, 2013.

[84] A. Seco, F. Ramírez, L. Miqueleiz, and B. García, "Stabilization of expansive soils for use in construction," Applied Clay Science, vol. 51, no. 3, pp. 348-352, 2011.

[85] M. R. Taha, "Geotechnical properties of soil-ball milled soil mixtures," in Nanotechnology in Construction 3, Z. Bittnar, P. J. M. Bartos, J. Němeček et al., Eds., pp. 377-382, Springer, Berlin, Germany, 2009.

[86] R. P. Freitas, V. S. Felix, M. O. Pereira et al., "Micro-XRF analysis of a Brazilian polychrome sculpture," Microchemical Journal, vol. 149, p. 104020, 2019.

[87] A. Modarres and Y. M. Nosoudy, "Clay stabilization using coal waste and lime-technical and environmental impacts," Applied Clay Science, vol. 116-117, pp. 281-288, 2015.

[88] M. Khemissa and A. Mahamedi, "Cement and lime mixture stabilization of an expansive overconsolidated clay," Applied Clay Science, vol. 95, pp. 104-110, 2014.

[89] K. M. A. Hossain, M. Lachemi, and S. Easa, "Stabilized soils for construction applications incorporating natural resources of Papua New Guinea," Resources, Conservation and Recycling, vol. 51, no. 4, pp. 711-731, 2007.

[90] A. K. Sabat, "Engineering properties of an expansive soil stabilized with rice husk ash and lime sludge," International Journal of Engineering and Technology, vol. 5, no. 6, pp. 4826-4833, 2013.

[91] B.-W. Yu, Y.-J. Du, F. Jin, and C.-Y. Liu, "Multiscale study of sodium sulfate soaking durability of low plastic clay stabilized by reactive magnesia-activated ground granulated blast-furnace slag," Journal of Materials in Civil Engineering, vol. 28, no. 6, Article ID 04016016, 2016.

[92] A. Rana, P. Kalla, and L. J. Csetenyi, "Sustainable use of marble slurry in concrete," Journal of Cleaner Production, vol. 94, pp. 304-311, 2015.

[93] F. Oriola and G. Moses, "Groundnut shell ash stabilization of black cotton soil," Electronic Journal of Geotechnical Engineering, vol. 15, no. 1, pp. 415-428, 2010.

[94] K. M. A. Hossain and L. Mol, "Some engineering properties of stabilized clayey soils incorporating natural pozzolans and industrial wastes," Construction and Building Materials, vol. 25, no. 8, pp. 3495-3501, 2011.

[95] A. K. Sharma and P. V. Sivapullaiah, "Ground granulated blast furnace slag amended fly ash as an expansive soil stabilizer," Soils and Foundations, vol. 56, no. 2, pp. 205-212, 2016.

[96] J. M. Kate, "Strength and Volume Change Behavior of Expansive Soils Treated with Fly Ash," Innovations in Grouting and Soil Improvement, American Society of Civil Engineers, Reston, VA, USA, pp. 1-15, 2005.

[97] P. Dahale, P. Nagarnaik, and A. Gajbhiye, "Effect OF flyash and lime on stabilization of expansive soil," Journal on Civil Engineering, vol. 6, no. 2, p. 8, 2016.

[98] A. A. Al-Rawas, "Microfabric and mineralogical studies on the stabilization of an expansive soil using cement by-pass dust and some types of slags," Canadian Geotechnical Journal, vol. 39, no. 5, pp. 1150-1167, 2002.

[99] S. Kolias, V. Kasselouri-Rigopoulou, and A. Karahalios, "Stabilisation of clayey soils with high calcium fly ash and cement," Cement and Concrete Composites, vol. 27, no. 2, pp. 301-313, 2005.

[100] M. Dayioglu, B. Cetin, and S. Nam, "Stabilization of expansive Belle Fourche shale clay with different chemical additives," Applied Clay Science, vol. 146, pp. 56-69, 2017.

[101] I. Akinwumi, "Soil modification by the application of steel slag," Periodica Polytechnica Civil Engineering, vol. 58, no. 4, pp. 371-377, 2014.

[102] L.-W. Kong and A.-G. Guo, "Bearing strength and swelling behavior of jingmen expansive soil," in Proceedings of the GeoFlorida 2010: Advances in Analysis, Modeling \& Design, pp. 2571-2580, Palm Beach, FL, USA, February 2010.

[103] E. R. Sujatha, K. Dharini, and V. Bharathi, "Influence of groundnut shell ash on strength and durability properties of clay," Geomechanics and Geoengineering, vol. 11, no. 1, pp. 20-27, 2016.

[104] M. Dafalla, E. Mutaz, and M. Al-Shamrani, "Compressive strength variations of lime-treated expansive soils," in Proceedings of the International Foundations Congress and Equipment Expo, pp. 1402-1409, San Antonio, TX, USA, March 2015.

[105] T. Y. Elkady, "The effect of curing conditions on the unconfined compression strength of lime-treated expansive soils," Road Materials and Pavement Design, vol. 17, no. 1, pp. 52-69, 2016. 
[106] A. A. B. Moghal, B. C. S. Chittoori, and B. M. Basha, "Effect of fibre reinforcement on CBR behaviour of lime-blended expansive soils: reliability approach," Road Materials and Pavement Design, vol. 19, no. 3, pp. 690-709, 2018.

[107] M. R. Hausmann, Engineering Principles of Ground Modification, McGraw-Hill, New York, Ny, USA, 1990.

[108] D. Bergado, L. Anderson, N. Miura, and A. Balasubramaniam, Soft Ground Improvement in Lowland and Other Environments, ASCE, Reston, VA, USA, 1996.

[109] A. R. Goodarzi and M. Salimi, "Stabilization treatment of a dispersive clayey soil using granulated blast furnace slag and basic oxygen furnace slag," Applied Clay Science, vol. 108, pp. 61-69, 2015.

[110] F. G. Bell, Engineering Treatment of Soils, CRC Press, Boca Raton, FL, USA, 2014.

[111] M. F. Javed, N. H. Ramli Sulong, S. A. Memon, S. K.-u. Rehman, and N. B. Khan, "Experimental and numerical study of flexural behavior of novel oil palm concrete filled steel tube exposed to elevated temperature," Journal of Cleaner Production, vol. 205, pp. 95-114, 2018.

[112] T. Thyagaraj, S. M. Rao, P. Sai Suresh, and U. Salini, "Laboratory studies on stabilization of an expansive soil by lime precipitation technique," Journal of Materials in Civil Engineering, vol. 24, no. 8, pp. 1067-1075, 2012.

[113] T. Olinic and E. Olinic, "The effect of quicklime stabilization on soil properties," Agriculture and Agricultural Science Procedia, vol. 10, pp. 444-451, 2016.

[114] L. Ali and Z. Zafar, "Construction on expansive soils in semi arid zone," in Proceedings of the Instrumentation, Testing, and Modeling of Soil and Rock Behavior, American Society of Civil Engineers, Hunan, China, June 2011.

[115] S. K. Dash and M. Hussain, "Lime stabilization of soils: reappraisal," Journal of Materials in Civil Engineering, vol. 24, no. 6, pp. 707-714, 2011.

[116] Y. Cheng, S. Wang, J. Li, X. Huang, C. Li, and J. Wu, "Engineering and mineralogical properties of stabilized expansive soil compositing lime and natural pozzolans," Construction and Building Materials, vol. 187, pp. 1031-1038, 2018.

[117] F. G. Bell, "Lime stabilization of clay minerals and soils," Engineering Geology, vol. 42, no. 4, pp. 223-237, 1996.

[118] M. Al-Mukhtar, S. Khattab, and J.-F. Alcover, "Microstructure and geotechnical properties of lime-treated expansive clayey soil," Engineering Geology, vol. 139-140, pp. 17-27, 2012.

[119] S. Horpibulsuk, R. Rachan, A. Chinkulkijniwat, Y. Raksachon, and A. Suddeepong, "Analysis of strength development in cement-stabilized silty clay from microstructural considerations," Construction and Building Materials, vol. 24, no. 10, pp. 2011-2021, 2010.

[120] A. M. Idris and A. A. El-Zahhar, "Indicative properties measurements by SEM, SEM-EDX and XRD for initial homogeneity tests of new certified reference materials," Microchemical Journal, vol. 146, pp. 429-433, 2019.

[121] R. L. Buhler and A. B. Cerato, "Stabilization of Oklahoma expansive soils using lime and class C FLY ash," in Proceedings of the Problematic Soils and Rocks and in Situ Characterization, pp. 1-10, Denver, Co, USA, February 2007.

[122] C. Shi, "Studies on several factors affecting hydration and properties of lime-pozzolan cements," Journal of Materials in Civil Engineering, vol. 13, no. 6, pp. 441-445, 2001.

[123] M. M. Zumrawi and A. A.-A. A. Babikir, "Laboratory study of steel slag used for stabilizing expansive soil," University of Khartoum Engineering Journal, vol. 6, no. 2, 2017.
[124] G. Constantinides, "Nanoscience and nanoengineering of cement-based materials," in Nanotechnology in Eco-Efficient Construction, Elsevier, Amsterdam, Netherlands, 2013.

[125] A. Jamshidi, K. Kurumisawa, T. Nawa, and T. Igarashi, "Performance of pavements incorporating waste glass: the current state of the art," Renewable and Sustainable Energy Reviews, vol. 64, pp. 211-236, 2016.

[126] A. Grilli, E. Bocci, and A. Graziani, "Influence of reclaimed asphalt content on the mechanical behaviour of cementtreated mixtures," Road Materials and Pavement Design, vol. 14, no. 3, pp. 666-678, 2013.

[127] A. S. Zaimoglu, "Optimization of unconfined compressive strength of fine-grained soils modified with polypropylene fibers and additive materials," KSCE Journal of Civil Engineering, vol. 19, no. 3, pp. 578-582, 2015.

[128] M. Schneider, M. Romer, M. Tschudin, and H. Bolio, "Sustainable cement production-present and future," $\mathrm{Ce}$ ment and Concrete Research, vol. 41, no. 7, pp. 642-650, 2011.

[129] Z. He, X. Zhu, J. Wang, M. Mu, and Y. Wang, "Comparison of $\mathrm{CO} 2$ emissions from $\mathrm{OPC}$ and recycled cement production," Construction and Building Materials, vol. 211, pp. 965-973, 2019.

[130] S. Saride, S. R. Chikyala, A. J. Puppala, and P. J. Harris, "Effects of organics on stabilized expansive subgrade soils," in Proceedings of the Ground Improvement and Geosynthetics, pp. 155-164, Conshohocken, PA, USA, 2010.

[131] M. Turkoz and H. Tosun, "The use of methylene blue test for predicting swell parameters of natural clay soils," Scientific Research and Essays, vol. 6, no. 8, pp. 1780-1792, 2011.

[132] M. Rahman, S. Rehman, and O. Al-Amoudi, "Literature review on cement kiln dust usage in soil and waste stabilization and experimental investigation," International Journal of Research and Reviews in Applied Sciences, vol. 7, no. 1, pp. 77-87, 2011.

[133] R. A. Shawabkeh, "Solidification and stabilization of cadmium ions in sand-cement-clay mixture," Journal of Hazardous Materials, vol. 125, no. 1-3, pp. 237-243, 2005.

[134] S. Peethamparan and J. Olek, "Study of the effectiveness of cement kiln dusts in stabilizing Na-Montmorillonite clay," Journal of Materials in Civil Engineering, vol. 20, no. 2, pp. 137-146, 2008.

[135] S. Peethamparan, J. Olek, and J. Lovell, "Influence of chemical and physical characteristics of cement kiln dusts (CKDs) on their hydration behavior and potential suitability for soil stabilization," Cement and Concrete Research, vol. 38, no. 6, pp. 803-815, 2008.

[136] S. L. Cui, J. D. Wang, X. D. Wang, Y. F. Du, and X. P. Wang, "Mechanical behavior and micro-structure of cement kiln dust-stabilized expensive soil," Arabian Journal of Geosciences, vol. 11, no. 17, p. 521, 2018.

[137] D.-F. Lin, K.-L. Lin, M.-J. Hung, and H.-L. Luo, "Sludge ash/ hydrated lime on the geotechnical properties of soft soil," Journal of Hazardous Materials, vol. 145, no. 1-2, pp. 58-64, 2007.

[138] Q.-Y. Ma, Z.-M. Cao, and P. Yuan, "Experimental research on microstructure and physical-mechanical properties of expansive soil stabilized with fly ash, sand, and basalt fiber," Advances in Materials Science and Engineering, vol. 2018, Article ID 9125127, 13 pages, 2018.

[139] F. E. Jalal, K. Shahzada, S. Saeed, I. Ahmad, and K. Khan, "Stabalization of medium expansive soils in Pakistan using marble industrial waste and bagasse ash," International Journal of Earth Sciences and Engineering, vol. 10, no. 4, pp. 885-891, 2017. 
[140] R. Alavéz-Ramírez, P. Montes-García, J. Martínez-Reyes, D. C. Altamirano-Juárez, and Y. Gochi-Ponce, "The use of sugarcane bagasse ash and lime to improve the durability and mechanical properties of compacted soil blocks," Construction and Building Materials, vol. 34, pp. 296-305, 2012.

[141] C. Okagbue and T. Onyeobi, "Potential of marble dust to stabilise red tropical soils for road construction," Engineering Geology, vol. 53, no. 3-4, pp. 371-380, 1999.

[142] A. Mahamedi and M. Khemissa, "Stabilization of an expansive overconsolidated clay using hydraulic binders," HBRC Journal, vol. 11, no. 1, pp. 82-90, 2015.

[143] J. D. J. A. Baldovino, R. L. D. S. Izzo, E. B. Moreira, and J. L. Rose, "Optimizing the evolution of strength for limestabilized rammed soil," Journal of Rock Mechanics and Geotechnical Engineering, vol. 11, no. 4, pp. 882-891, 2019.

[144] L.-X. Mao, Z. Hu, J. Xia et al., "Multi-phase modelling of electrochemical rehabilitation for ASR and chloride affected concrete composites," Composite Structures, vol. 207, pp. 176-189, 2019.

[145] Q. T. Phung, N. Maes, and S. Seetharam, "Pitfalls in the use and interpretation of TGA and MIP techniques for Caleached cementitious materials," Materials \& Design, vol. 182, p. 108041, 2019.

[146] F. S. Pereira, E. R. deAzevedo, E. F. da Silva et al., "Study of the carbon dioxide chemical fixation-activation by guanidines," Tetrahedron, vol. 64, no. 43, pp. 10097-10106, 2008.

[147] A. Dulaimi, H. A. Nageim, F. Ruddock, and L. Seton, "Performance analysis of a cold asphalt concrete binder course containing high-calcium fly ash utilizing waste material," Journal of Materials in Civil Engineering, vol. 29, no. 7, Article ID 04017048, 2017.

[148] S.-G. Lu, F.-F. Sun, and Y.-T. Zong, "Effect of rice husk biochar and coal fly ash on some physical properties of expansive clayey soil (Vertisol)," Catena, vol. 114, pp. 37-44, 2014.

[149] ASTM, Standard Specification for Coal Fly Ash and Raw or Calcined Natural Pozzolan for Use in Concrete, ASTM, West Conshohocken, PA, USA, 2012.

[150] Q. Zeng, K. Li, T. Fen-chong, and P. Dangla, "Determination of cement hydration and pozzolanic reaction extents for flyash cement pastes," Construction and Building Materials, vol. 27, no. 1, pp. 560-569, 2012.

[151] B. Lin and A. B. Cerato, "Applications of SEM and ESEM in microstructural investigation of shale-weathered expansive soils along swelling-shrinkage cycles," Engineering Geology, vol. 177, pp. 66-74, 2014.

[152] B. R. Phani Kumar and R. S. Sharma, "Effect of fly ash on engineering properties of expansive soils," Journal of Geotechnical and Geoenvironmental Engineering, vol. 130, no. 7, pp. 764-767, 2004.

[153] S. Kommu, S. S. Asadi, and A. V. S. Prasad, "Leaching behavior and strength characteristics of black cotton soil stabilized with fly ash," Materials Today: Proceedings, vol. 5, no. 9, pp. 17974-17981, 2018.

[154] A. R. Pourkhorshidi, M. Najimi, T. Parhizkar, F. Jafarpour, and B. Hillemeier, "Applicability of the standard specifications of ASTM C618 for evaluation of natural pozzolans," Cement and Concrete Composites, vol. 32, no. 10, pp. 794800, 2010.

[155] C. Gupta and R. K. Sharma, "Influence of marble dust, fly ash and beas sand on sub grade characteristics of expansive soil," Journal of Mechanical and Civil Engineering, pp. 13-18, 2014.

[156] D. C. Sekhar and S. Nayak, "Utilization of granulated blast furnace slag and cement in the manufacture of compressed stabilized earth blocks," Construction and Building Materials, vol. 166, pp. 531-536, 2018.

[157] M. Temimi, M. A. Rahal, M. Yahiaoui, and R. Jauberthie, "Recycling of fly ash in the consolidation of clay soils," Resources, Conservation and Recycling, vol. 24, no. 1, pp. 1-6, 1998.

[158] I. Azim, J. Yang, S. Bhatta, F. Wang, and Q.-f. Liu, "Factors influencing the progressive collapse resistance of RC frame structures," Journal of Building Engineering, p. 100986, 2019.

[159] P. Sivapullaiah, Use of Solid Waste to Enhance Properties of Problematic Soil of Karnataka, Indian Institute of Science, Bangalore, India, 2014.

[160] N.-J. Jiang, Y.-J. Du, and K. Liu, "Durability of lightweight alkali-activated ground granulated blast furnace slag (GGBS) stabilized clayey soils subjected to sulfate attack," Applied Clay Science, vol. 161, pp. 70-75, 2018.

[161] A. A. Ashango and N. R. Patra, "Behavior of expansive soil treated with steel slag, rice husk ash, and lime," Journal of Materials in Civil Engineering, vol. 28, no. 7, Article ID 06016008, 2016.

[162] J. T. Hatmoko and H. Suryadharma, "Shear behavior of calcium carbide residue - bagasse ash stabilized expansive soil," Procedia Engineering, vol. 171, pp. 476-483, 2017.

[163] M. De Beer, Behaviour of Cementitious Subbase Layers in Bitumen Base Road Structures, University of Pretoria, Pretoria, South Africa, 2009.

[164] K. Ganesan, K. Rajagopal, and K. Thangavel, "Evaluation of bagasse ash as supplementary cementitious material," $\mathrm{Ce}$ ment and Concrete Composites, vol. 29, no. 6, pp. 515-524, 2007.

[165] W. Fedrigo, A. T. Visser, W. J. Steyn, and W. P. Núñez, "Flexural behaviour of lightly Cement stabilised materials: South Africa and Brazil," Road Materials and Pavement Design, pp. 1-26, 2019.

[166] K. C. P. Faria, R. F. Gurgel, and J. N. F. Holanda, "Recycling of sugarcane bagasse ash waste in the production of clay bricks," Journal of Environmental Management, vol. 101, pp. 7-12, 2012.

[167] L. D. Nguyen, B. Fatahi, and H. Khabbaz, "A constitutive model for cemented clays capturing cementation degradation," International Journal of Plasticity, vol. 56, pp. 1-18, 2014.

[168] A. K. Yadav, K. Gaurav, R. Kishor, and S. Suman, "Stabilization of alluvial soil for subgrade using rice husk ash, sugarcane bagasse ash and cow dung ash for rural roads," International Journal of Pavement Research and Technology, vol. 10, no. 3, pp. 254-261, 2017.

[169] S. Horpibulsuk, C. Phetchuay, and A. Chinkulkijniwat, "Soil stabilization by calcium carbide residue and fly ash," Journal of Materials in Civil Engineering, vol. 24, no. 2, pp. 184-193, 2011.

[170] C. Subhacini, M. Ranjitha, S. Dhanapal, and K. A. Prakash, "Expansive soil stabilization using waste from sugarcane Industry," Journal for Studies in Management and Planning, vol. 1, no. 3, pp. 345-352, 2015.

[171] K. Somna, C. Jaturapitakkul, and P. Kajitvichyanukul, "Microstructure of calcium carbide residue-ground fly ash paste," Journal of Materials in Civil Engineering, vol. 23, no. 3, pp. 298-304, 2010.

[172] S. Vichan and R. Rachan, "Chemical stabilization of soft Bangkok clay using the blend of calcium carbide residue and biomass ash," Soils and Foundations, vol. 53, no. 2, pp. 272-281, 2013. 
[173] A. K. Sabat, "Utilization of bagasse ash and lime sludge for construction of flexible pavements in expansive soil areas," Electronic Journal of Geotechnical Engineering, vol. 17, pp. 1037-1046, 2012.

[174] B. Madhusudhana, "A survey on area, production and productivity of groundnut crop in India," IOSR Journal of Economics and Finance, vol. 1, no. 3, pp. 1-7, 2013.

[175] N. Gajera, K. Thanki, N. Gajera, and K. Thanki, "Stabilization analysis of black cotton soil by using groundnut shell ash," International Journal for Innovative Research in Science \& Technology, vol. 2, no. 1, pp. 158-162, 2015.

[176] K. Venkatraman, P. Dayakar, R. Venkatakrishnaiah, and B. BIST, "Study ON effect OF groundnut shell ash IN index properties OF clay soil," International Journal of Pure and Applied Mathematics, vol. 119, no. 12, pp. 9265-9277, 2018.

[177] M. H. Zhang, R. Lastra, and V. M. Malhotra, "Rice-husk ash paste and concrete: some aspects of hydration and the microstructure of the interfacial zone between the aggregate and paste," Cement and Concrete Research, vol. 26, no. 6, pp. 963-977, 1996.

[178] A. Kampala and S. Horpibulsuk, "Engineering properties of silty clay stabilized with calcium carbide residue," Journal of Materials in Civil Engineering, vol. 25, no. 5, pp. 632-644, 2012.

[179] D. C. Su and J. W. C. Wong, "Chemical speciation and phytoavailability of $\mathrm{Zn}, \mathrm{Cu}, \mathrm{Ni}$ and $\mathrm{Cd}$ in soil amended with fly ash-stabilized sewage sludge," Environment International, vol. 29, no. 7, pp. 895-900, 2004.

[180] M. M. Ai-sharif and M. F. Attom, "A geoenvironmental application of burned wastewater sludge ash in soil stabilization," Environmental Earth Sciences, vol. 71, no. 5, pp. 2453-2463, 2014.

[181] L. Chen and D.-F. Lin, "Stabilization treatment of soft subgrade soil by sewage sludge ash and cement," Journal of Hazardous Materials, vol. 162, no. 1, pp. 321-327, 2009.

[182] H. Gadouri, K. Harichane, and M. Ghrici, "Effect of sodium sulphate on the shear strength of clayey soils stabilised with additives," Arabian Journal of Geosciences, vol. 10, no. 10, p. 218, 2017.

[183] W. Gong, Y. M. Tien, C. H. Juang, J. R. Martin II, and J. Zhang, "Calibration of empirical models considering model fidelity and model robustness-focusing on predictions of liquefaction-induced settlements," Engineering Geology, vol. 203, pp. 168-177, 2016. 